\title{
„Naderwany" sejm konwokacyjny w 1696 r. Uwagi o nieodzowności historii prawa na marginesie pracy Ewy Gąsior ${ }^{1}$
}

\section{UWAGI WSTĘPNE}

Sejmy konwokacyjne należy uznać niewątpliwie za jedne z najbardziej interesujących rodzajów staropolskich sejmów walnych, które nie cieszyły się jak dotąd szczególnym zainteresowaniem literatury przedmiotu². Problem liberum veto i zjawisko zrywania sejmów to z kolei kluczowe zagadnienia dla zrozumienia nie tylko dziejów staropolskiego parlamentaryzmu, ale również dla generalnej oceny staropolskiego ustroju politycznego ${ }^{3}$. W konsekwencji monografia pióra Ewy

${ }^{1}$ E. Gąsior, Sejm konwokacyjny po śmierci Jana III Sobieskiego, Warszawa 2017, ss. 315. Jest to opublikowana wersja rozprawy doktorskiej: E. Gąsior, Sejm konwokacyjny w okresie bezkrólewia po śmierci Jana III Sobieskiego, Uniwersytet Pedagogiczny im. Komisji Edukacji Narodowej w Krakowie. Wydział Humanistyczny. Praca doktorska napisana pod kierunkiem prof. dr hab. Bożeny Popiołek, Kraków 2013.

2 Szkic konwokacjom poświęcił W. Konopczyński, Konwokacje, [w:] Studia historyczne ku czci Stanisława Kutrzeby, t. I, Kraków 1938. Sporo uwag sejmowi konwokacyjnemu z 1632 r. poświecił monografista obu sejmów bezkrólewia po śmierci Zygmunta III Wazy - W. Kaczorowski, Sejmy konwokacyjny i elekcyjny w okresie bezkrólewia 1632 r., Opole 1986. Nieco informacji zawiera klasyczne studium o sejmie epoki oligarchii pióra H. Olszewskiego, Sejm w dawnej Rzeczypospolitej. Ustrój i idee, Poznań 2002, t. 1 s. 426-433.

${ }^{3}$ Zagadnienie to ma oczywiście bardzo szeroką literaturę przedmiotu. Klasyczne studium W. Konopczyńskiego (Liberum veto. Studium porównawczo-historyczne, Kraków 2002), większość doktryny - i słusznie jak się zdaje - uznaje za ujęcie nieobiektywnie krytyczne wobec zasady zgody i jednomyślnego podejmowania uchwał. Najistotniejszą polemikę z tym poglądem wykazuje koncepcja I. Lewandowskiej-Malec, „Zapomniana demokracja”. O demokracji deliberatywnej w Pierwszej Rzeczypospolitej, „Studia Iuridica Toruniensia”, 2012, X, s. 123-146, przyrównująca sposób prowadzenia sejmowych debat do habermasowskiego ideału „demokracji deliberatywnej”. 
Gąsior poświęcona sejmowi konwokacyjnemu z 1696 r. (jedynemu sejmowi tego rodzaju, który został zerwany jednostkowym sprzeciwem posła), musiała wzbudzić zainteresowanie nauki historii prawa.

Pierwotnym założeniem autora niniejszego szkicu było opracowanie szerokiej recenzji pracy, której problematyka ma tak ogromne znaczenie. Po wnikliwym zapoznaniu się z treścią pracy koncepcja ta uległa diametralnej zmianie. Przede wszystkim dlatego, że najważniejsza część rozważań Autorki - kwestia zerwania sejmu konwokacyjnego - pozostawia dużo do życzenia. Dotyczy to zarówno aspektów politycznych (które były głównym przedmiotem zainteresowania Autorki), jak również, a może raczej przede wszystkim, problemów prawnych omawianego zagadnienia.

Rozważaniom tej skomplikowanej i trudnej kwestii poświęcono w monografii bardzo niewiele miejsca i uwagi ${ }^{4}$. Nieliczne refleksje Autorki w tym zakresie są nie tylko mało pogłębione, ale i wewnętrznie sprzeczne. Znacząco obniża to wartość pracy, wzywając historyka prawa do zabrania głosu. Niniejszy artykuł nie zdoła oczywiście wypełnić roli kompleksowej monografii omawianego sejmu. Powinien jednak pozwolić na chociażby uporządkowanie podstawowych kwestii związanych z jego zerwaniem. Stanowić będzie również próbę sformułowania kilku uwag warsztatowych w kwestii tworzenia prac historycznych, w których

Kilka studiów zawiera ciekawą argumentację w obronie jednomyślności, por. m.in. C. Backvis, Wymóg jednomyślności a wola ogólu, „Czasopismo Prawno-Historyczne” 1975, t. XXVII, z. 2, s. 161-173 oraz D. Rohac, The Unanimity Rule and Religious Fractionalisation in the Polish-Lithuanian Republic, „Constitutional Political Economy” 2008, vol. 19, No. 2, s. 111-128. Sprawie konkluzji sejmowych poświęcano osobne szkice, por. I. Lewandowska- Malec, „Tragedya conclusyey seymowey”. Rozważania o formie i materii, [w:] J. Przygodzki, M.J. Ptak (red.), Społeczeństwo a władza. Ustrój, prawo idee, Wrocław 2010, s. 253-264. J. Choińska-Mika, Od zgody wszystkich do jednomyślności - modus concludendi sejmów polskich za ostatnich Wazów [w:] S. Grodziski, D. Malec, A. Karabowicz, M. Stus (red.), Vetera novis augere. Studia i prace dedykowane Profesorowi Wacławowi Uruszczakowi, t. I, Kraków 2010. Cenne informacje o praktyce liberum veto na określonych etapach rozwoju staropolskiego parlamentaryzmu zawierają monografie sejmów w dłuższych perspektywach chronologicznych - I. Lewandowska-Malec, Sejm walny koronny Rzeczypospolitej Obojga Narodów i jego dorobek ustawodawczy: 15871632, Kraków 2009, passim; S. Ochmann-Staniszewska, Z. Staniszewski, Sejm Rzeczypospolitej za panowania Jana Kazimierza Wazy: Prawo, doktryna, praktyka. Wrocław 2000, t. II, passim; R. Kołodziej, ,Ostatni wolności naszej klejnot”. Sejm Rzeczypospolitej za panowania Jana III Sobieskiego, Poznań 2014, passim, H. Olszewski, op.cit., passim. Szereg cennych informacji zawierają monografie poszczególnych sejmów walnych, których wymienienie - dla ilości tego typu publikacji - wydaje się niecelowe. Na osobne wyeksponowanie zasługuje praca zbiorowa pod redakcją Stefanii Ochmann-Staniszewskiej (Uchwalanie konstytucji na sejmach w XVI-XVIII w., Wrocław 1979).

${ }^{4} \mathrm{Na}$ podrozdział zatytułowany Zerwanie sejmu konwokacyjnego, poświęcono co prawda nieco ponad 15 stron, E. Gąsior, op.cit., s. 219-234, jednak właściwe rozważania dotyczące wydarzeń od zgłoszenia sprzeciwu przez posła Horodyńskiego aż do podpisania aktu konfederacji zajmują już tylko 5 i pół strony, ibidem, s. 229-234. 
kontekst polityczny wydarzeń splata się z aspektem prawnym tak silnie, że nie pozwala historykowi na uniknięcie zajmowania się problemami prawnymi.

Autorka monografii swój pogląd na zerwanie konwokacji wyraża dobitnie już we wstępie, pisząc, że „sejm kowokacyjny zwał się konfederacją generalną, czyli odbywał się sub vinculo confoedarationis". Konfederacja taka - postrzegana chyba przez Autorkę raczej jako organ władzy, a nie związek obywateli - miała stanowić prawo większością głosów. Nie stosowano zatem na mocy jej węzła reguł zasady zgody (wymagającej w aspekcie technicznym jednomyślnej, bo wykluczającej jednostkowy sprzeciw, aprobaty rozwiązań prawnych przez wszystkich uczestników obrad). Doprowadziło to Autorkę do wniosku, że odwołanie się przez jednego posła do liberum veto i w konsekwencji zerwanie konwokacji było niedopuszczalne.

Jak zatem komentuje Ewa Gąsior fakt, że konwokacja w roku 1696 roku została mimo wszystko zerwana przez jednostkowy sprzeciw posła Horodyńskiego? Otóż twierdzi ona, że stało się to możliwe dzięki temu, że sejmujący, wbrew prawu, „uznali” po prostu sejm za zerwany. Jednocześnie dodaje, że „uczestnicy" sejmu, mimo jego zerwania, podpisali akt konfederacji generalnej. Zaznacza jedynie, ,że większość zebranych uczyniła to z zastrzeżeniami”. Późniejsza argumentacja Autorki w tym przedmiocie stanowi powtórzenie tej tezy z niewielkimi uzupełnieniami ${ }^{6}$.

Już na pierwszy rzut oka uderza fakt, że w monografii nie wykorzystano uwag dotychczasowej literatury, dotyczącej funkcjonowania staropolskiego parlamentaryzmu, Autorka nie powołała się w ogóle na pracę Roberta Kołodzieja o sejmie z czasów Jana III $^{7}$. Klasyczna praca Henryka Olszewskiego o sejmie epoki oligarchii pojawia się jedynie w spisie bibliograficznym i nie została w kontekście omawianego problemu powołana w przypisach pracy $^{8}$. Autorka porusza przy tym problematykę konfederacji, którą próbuje opisać bez odniesienia do kluczowego dla tego zagadnienia studium Wojciecha Stanka. Praca Stanka jest niestety silnie lekceważona w literaturze, mimo przełomowych, a przy tym świetnie udokumentowanych źródłowo tez ${ }^{9}$. Ewa Gąsior - co prawda - wskazuje omawianą monografię w nocie bibliograficznej, ale w treści pracy nie powołuje jej ani razu.

5 Ibidem, s. 10.

${ }^{6}$ Por. ibidem, s. 232.

${ }^{7}$ R. Kołodziej, op.cit., passim.

${ }^{8}$ Została ona zresztą przywołana, poza wstępem, tylko w jednym miejscu - E. Gąsior, op.cit., s. 68 , przyp. nr 228 .

9 Autor, poza szerokim uzasadnieniem wielu nieznanych elementów organizacji porządku konfederacyjnego i jego relacji z innymi, stałymi organami, kwestionuje przede wszystkim tezę o podejmowaniu przez organy konfederacyjne decyzji większością głosów aż do czasów stanisławowskich, W. Stanek, Konfederacje generalne koronne w XVIII wieku, Torun 1991, s. 46 i n. 
Formułuje przy tym twierdzenia sprzeczne z ustaleniami Stanka, nie odnosząc się do jego monografii polemicznie i nie przytaczając w tej mierze stosownej argumentacji. Sprawia to wrażenie wskazania tej monografii w nocie bibliograficznej zupełnie pro forma, bez jej właściwego zanalizowania czy wprost - bez wnikliwego zapoznania się z jej treścią.

Oczywiście praca Ewy Gąsior to nie studium prawne czy historycznoprawne. Jednakże bez wyjaśnienia kwestii prawnych problemy sporów politycznych okazują się zupełnie wyabstrahowane z kontekstu i niezrozumiałe. Żeby prawidłowo zrozumieć, zwłaszcza postawę głównych aktorów sceny politycznej w napiętych realiach bezkrólewia (przy zaognionym, wielowątkowym i wielopoziomowym konflikcie politycznym) konieczne jest zrekonstruowanie ich stosunku do instytucji prawnych oraz wskazanie uznawanych przez ich kulturę polityczną ograniczeń, które system prawny na nich nakładał. Dopiero wtedy ich wybory i decyzje oraz dylematy za nimi stojące staną się klarowne. Jest to nieodzowne nawet wówczas, jeśli uznamy - co jest nie do końca prawdą - że szlachta polska używała prawa i interpretacji prawnych wyłącznie instrumentalnie ${ }^{10}$.

W dalszych częściach niniejszego artykułu postaram się pokrótce zaprezentować węzłowe problemy prawne związane z zerwaniem konwokacji z $1696 \mathrm{r}$., których brakuje w pracy Ewy Gąsior. Poniższe refleksje nie zastąpią oczywiście pełnego opracowania monograficznego. Będzie to raczej zbiór refleksji, pewien punkt wyjścia do właściwej oceny omawianego problemu. Po pierwsze, spróbuję prześledzić teoretyczne założenia i praktykę parlamentarną na sejmach konwokacyjnych zwłaszcza w drugiej połowie XVII wieku. Pozwoli to sprawdzić prawidłowość założenia, że konwokacje rzeczywiście decydowały większością głosów i nie można ich było zrywać jednostkowym sprzeciwem poselskim. Po drugie, prześledzę staropolską argumentację prawną odnoszącą się do zawiązywania bezkrólewiowych konfederacji generalnych na konwokacjach. Dzięki temu możliwe będzie zweryfikowanie pełnego utożsamienia konwokacji i konfederacji. Po trzecie, zaprezentuję podstawowe argumenty prawne dotyczące sprzeciwu Horodyńskiego (zaczerpnięte z aktu konfederacji, laudów sejmikowych, diariuszy sejmowych, publicystyki i korespondencji). Tym sposobem łatwiej będzie zrozumieć stosunek współczesnych do zerwania konwokacji i jego konsekwencji (tak politycznych, jak i prawnych).

${ }^{10}$ Należy pamiętać, że niepodważalny jest fakt odwoływania się w debacie publicznej do obowiązującego prawa i jego wykładni. Znajomość tego prawa i prawidłowe zrozumienie jego interpretacji jest zatem nieodzowne, nawet dla rekonstrukcji manipulacji i instrumentalizacji tejże argumentacji prawniczej. 


\section{TEORETYCZNE POGLĄDY I PRAKTYKA IUS VETANDI NA SEJMACH KONWOKACYJNYCH 1669-1733}

Punktem wyjścia dla rozważań Ewy Gąsior o zakończeniu sejmu konwokacyjnego w 1696 r. jest - jak już wspomniałem - przekonanie o prawnej niedopuszczalności zerwania takiego sejmu jednostkowym sprzeciwem. Autorka thumaczy jednak, że konwokacja została skutecznie zerwana, ponieważ, zupełnie wyjątkowo, taki jednostkowy sprzeciw „uznano" ${ }^{11}$. Konstatacja ta jest w zasadzie sprzeczna logicznie ${ }^{12}$. Autorka nie przywołała tu niestety intrygującej opinii Henryka Olszewskiego, który wskazywał, że kategorie legalności (bądź nie) określonych procedur na staropolskich sejmach walnych, szczególnie konwokacyjnych, zależały zawsze wyłącznie od woli bieżącego składu sejmującego ${ }^{13}$. Zgodnie $\mathrm{z}$ tym punktem widzenia prawne i teoretyczne założenia dotyczące funkcjonowania sejmu były zawsze tylko umowne i mogły być w pełni elastycznie kształtowane przez każdorazowo odbywane zgromadzenie. Takie podejście jest logicznie spójne - w przeciwieństwie do stanowiska Ewy Gąsior. Moim zdaniem nie wydaje się jednak do końca uzasadnione. Oznaczałoby bowiem w konsekwencji konieczność przyjęcia tezy o pełnej przypadkowości i niestałości albo wprost nieistnieniu systemu prawa i stabilnych instytucji prawnych w okresie staropolskim w odniesieniu do procedur parlamentarnych.

Staropolska doktryna prawna nie zostawia nam niestety szerokiego materiału do analizy kwestii ,zrywalności” sejmów konwokacyjnych. Nie budziło to bowiem szerszego zainteresowania teoretyków. Ciekawą interpretację omawianego problemu zawiera traktat z 1 poł. XVIII w., pt. Rząd Polski. Szkoda, że Autorka nie skorzystała $\mathrm{z}$ tego źródła, ponieważ nawet semantycznie opinia w nim wyrażona została skonstruowane łudząco podobnie do jej rozważań. Anonimowy twórca traktatu konstatuje bowiem, że konwokacja „,agituie się pod imieniem Konfederacyi generalney", w związku z czym ,zerwać się nie może"14. Ten sam autor opisując jednak kwestie typowo historyczne w pracy Monarchowie Polscy, pisał po prostu o zerwaniu konwokacji, bez jakiegokolwiek komentarza dotyczącego

${ }^{11}$ E. Gąsior, op.cit., s. 10, 232.

12 Skoro istniała obowiązująca i klarowna norma prawna zakazująca zrywania sejmów, to nie można było przecież ,uznać” jej tak po prostu za nieobowiązującą w danej sytuacji. Jeśli mimo to dokonano takiej interpretacji, to trzeba by bliżej wyjaśnić stającą za tym argumentację prawną. Jednakże, logicznie rzecz biorąc, skoro możliwe było tak po prostu „uznanie” dopuszczalności zerwania takiego sejmu bez odwoływania się do jakiejkolwiek szczególnej interpretacji, to poddaje to w wątpliwość w ogóle istnienie w tym zakresie stanowczego i respektowanego zakazu prawnego.

${ }_{13}$ Pisze on o konwokacjach: „Teoretyczne rozważania nie miały większego znaczenia: wszelkie wątpliwości rozstrzygał każdorazowo aktualny układ sił politycznych w sejmie”, H. Olszewski, op.cit., s. 427.

${ }^{14}$ Biblioteka Zakładu Narodowego im. Ossolińskich we Wrocławiu [dalej: B. Ossol.] rkps. 52, s. $87-88$. 
nielegalności tego aktu ${ }^{15}$. O specyfice konwokacji i regule zakazu jej zrywania nie wspominają jednak dwa najpoważniejsze traktaty prawnicze XVIII wieku - Gotfryda Lengnicha i Wincentego Skrzetuskiego ${ }^{16}$.

Sprawą zajmował się, cytowany chętnie przez Autorkę monografii, Franciszek Salezy Jezierski. W swoim traktacie ujmował ten problem analogicznie jak Skrzetuski, bez jakichkolwiek zatrzeżeń o prawnej niedopuszczalności zerwania konwokacji. Więcej nawet, wprost osadzał epizod z 1696 r. w kontekście generalnego rozwoju liberum veto $\mathrm{w}$ staropolskim prawie ustrojowym i praktyce parlamentarnej. Komentował zatem: „Horodyński poseł czernichowski (...) seym konwokacyi pierwszy raz zerwał; czego dotąd nigdy nie bywało. Tą chorobą zrywania seymów zaraziła się Rzeczypospolita"17. Zerwanie konwokacji nie było zatem według niego faktem unikatowym i specyficznym, a tylko przejawem szerszego zjawiska stosowania radykalnej wykładni prawa wolnego głosu po roku 1652.

Reguł funkcjonowania parlamentaryzmu staropolskiego i dawnego prawa Rzeczypospolitej szlacheckiej nie sposób oceniać bez uwzględnienia perspektywy praktycznej. Oczywiście materiał do analizy jest niewielki. W dobie utrwalenia interpretacji zasady zgody, wymagającej pełnej jednomyślności, a więc po roku 1652 (symbolicznej dacie wprowadzenia możliwości zerwania sejmu przed czasem za pomocą sprzeciwu pojedynczego posła) a przed analizowanym sejmem z 1696 r., odbyły się zaledwie dwie konwokacje w 1668 i 1674 r. Ich przebieg wskazuje jednak na to, że reguły rządzące sejmami tego typu nie odbiegały od standardowych zasad charakterystycznych dla sejmów walnych dawnej Polski w ogólności.

W 1668 r. spotykamy na pierwszy rzut oka unikatową, a jednak symptomatyczną sytuację zgłoszenia sprzeciwu przez jednego z parlamentarzystów - w tym przypadku senatora i to nie byle jakiego, bo przewodniczącego senatowi prymasa.

15 Ibidem, s. 23.

16 Obaj uznawali - jak się zdaje - legalność zrywania konwokacji z 1696 r. Pisali bowiem zgodnie, że zastosowania liberum veto na tym sejmie było wydarzeniem unikatowym, nie formułowali jednak jakichkolwiek obiekcji prawnych. Żaden z nich nie powołuje się na normę niedopuszczalności zerwania sejmu. W ujęciu Lengnicha czytamy: „Lubo bowiem wiele w Polsce sejmów zrywano, wszelako konwokacyjne przynajmniej aż do roku 1696 udawały się, w którym Horodyński poseł z województwa czernichowskiego, przez swoje sprzeciwienie się, po raz pierwszy sejm takowy zerwał i przez to popadł w podejrzenie sprzedajności”, G. Lengnich, Prawo pospolite Królestwa Polskiego, Kraków 1836, s. 40-41. Zdaniem Skrzetuskiego sejm konwokacyjny „,w roku 1696, po upłynionym dwuniedzielnym czasie był ieszcze przewleczony, a na koniec zerwany; iedynym przykładem, bo seymy takowe zawsze dochodziły", W. Skrzetuski, Prawo Polityczne Narodu Polskiego, t. 1, Warszawa 1782, s. 270.

17 F.S. Jezierski, O bez-królewiach w Polszcze y wybieraniu królów począwszy od śmierci Zygmunta Augusta Jagiełly aż do naszych czasów, Warszawa 1790, s. 37-38. 
Wojciech Kriegseisen - w moim przekonaniu niesłusznie - uznał to wydarzenie za przejaw specyficznej pozycji interrexa na sejmach w bezkrólewiu ${ }^{18}$. Tej tezie przeczy wprost źródłowa opinia marszałka poselskiego - Jana Antoniego Chrapowickiego, który przytaczając sprzeciw obrażonego Prażmowskiego twierdził, że ten „wniósł o swoją wczorajszą krzywdę i porwał się odchodzić, z da jąc prymasowstwo Rzeczypospolitej [podkr. - T.K.]"19. Wyróżniony przeze mnie fragment o rezygnacji z godności prymasowskiej, był oczywiście raczej zabiegiem retorycznym aniżeli realną groźbą. Świadczy on jednak o tym, że Prażmowski nie powoływał się tu na jakieś mityczne uprawnienia interrexa, które wynikałyby z jego prymasowskiej godności. Jego sprzeciw był aktem senatora i szlachcica, dysponującego głosem wolnym w sejmie. Z perspektywy niniejszych rozważań kluczowe znaczenie ma reakcja zebranych, „porwali się wszyscy biskupi i senatorowie i zatrzymali go u mego [czyli marszałka Jana Antoniego Chrapowickiego - T.K.] stolika, perswadując, iżby powrócił, bo in aczej ze rwałby konwokacj ą [podkr. - T.K.]"20. Inny diariusz zostawił nam relację jeszcze bardziej dramatyczną; według niej prymas opuścił swe miejsce, a za nim „marszałek (...) ze wszystkim jego dworem ruszył a w tym za drzwiami przez Ichmciów panów senatorów i posłów zatrzymany (...) powrócił" ${ }^{21}$. Przebieg zdarzenia - choć w pewnym sensie wyjątkowego z uwagi na osobę kontradycenta - był raczej standardowy. Zgłoszenie sprzeciwu przez parlamentarzystę i jego wyjście z sali groziło zerwaniem sejmu. Protestującego należało zatem zatrzymać i przekonać do powrotu dla przywrócenia sejmowi activitas.

Na tym samym sejmie konwokacyjnym z 1668 r. spotykamy inny epizod, jeszcze bardziej charakterystyczny dla staropolskiego parlamentaryzmu z okresu po 1652 r., w newralgicznym dla każdego sejmu walnego momencie - tj. w trakcie dyskusji nad prolongacją obrad. Dnia 24 listopada posłowie województwa zakroczymskiego zgłosili sprzeciw i wyszli z sali. Marszałek konwokacji-Chrapowicki tak opisywał te wydarzenia: ,gdy się bardzo spóźniło, mówili o prolongacyjej - nie chcieli jedni powalać, drudzy, żeby jutro do juramentu przystępować, trzeci, żeby wraz i amnestia stawała"22. Emocje sięgnęły zenitu, co doprowadziło do przesilenia: ,panowie połowie zakroczmscy najbardziej zasadzali się i wyszli z protestacją publiczną"23. To stało się powodem rozpoczęcia żmudnego procesu

18 W. Kriegseisen, Sejm Rzeczypospolitej szlacheckiej (do 1763), Warszawa 1995, s. 105, $118-119$.

19 J.A. Chrapowicki, Diariusz. Cześć druga: lata 1665-1669, oprac. A. Rachuba, T. Wasilewski, Warszawa 1988, s. 456.

${ }^{20}$ Ibidem.

${ }^{21}$ Diariusz sejmu konwokacyjnego 1668 roku, wyd. K. Przyboś, Kraków 2009, s. 30-31.

22 J.A. Chrapowicki, op.cit., s. 458.

${ }^{23}$ Ibidem, s. 458-459. 
przekonywania posłów do powrotu i przywrócenia activitatem. Rolę mediatora pełnił z urzędu marszałek poselski, którego zadaniem było w pierwszej kolejności zapobieżenie opuszczeniu przez posłów Warszawy (co pociągałoby za sobą konieczność uznania sejmu za zerwany). Negocjacje miały oczywiście doprowadzić do powrotu posłów do izby i formalnego wycofania przez nich sprzeciwu. Chrapowicki pisał: „długośmy się pocili, a najbardziej ja dla ukojenia onych”24. W lapidarnej relacji wyraźnie da się odczuć emocje, towarzyszące temu momentowi. Dzień obrad się kończył, sejm nie był prolongowany, a do tego został zgłoszony formalny sprzeciw grożący rozejściem się konwokacji bez podjęcia uchwał. W konsekwencji dopiero „przy świecach pozwolili na prolongacyją"25. Był to najbardziej dramatyczny, ale nie jedyny epizod tego typu w ostatnich dniach sejmu ${ }^{26}$.

Mało materiału pozostawia nam sprawnie przeprowadzony i raczej zgodny sejm konwokacyjny $1674 \mathrm{r}$. Nawet tutaj znajdujemy jednak potwierdzenie dla stosowania się do zasady braku sprzeciwu i uznawania jednostkowych sprzeciwów na ogólnych zasadach. Dnia 25 stycznia posłowie pruscy ,złożyli vetandi voces broniąc [tj. odmawiając, sprzeciwiając się - T.K.] activitatem czytania confoederacji", żądając wywodu indygenatu od świeżo mianowanego kasztelana gdańskiego ${ }^{27} .1$ lutego nie udało się podjąć decyzji w pewnej sprawie „obstante contradictione województwa Ruskiego posłów"28. W poniedziałek 19 lutego propozycja posłów sandomierskich w pewnej drobnej kwestii zyskała niemal powszechną aprobatę, jednak ,sam tylko Jeomć pisarz nurski temu restitit" ${ }^{29}$. W tym przypadku jednak sprawę udało się załatwić bez opuszczania przez kontradycenta izby poselskiej, autor diariusza zanotował, że „gęste panów Małopolskich instantie vicerunt, że tey ustąpił contradictiey" ${ }^{\prime 3}$. Kolejnego dnia grupa posłów, niewiadomej niestety liczebności, zablokowała propozycję klauzuli w akcie konfederacji generalnej: „obstante contradictione niektórych (...) zdrapano ten projekt”31.

24 Ibidem, s. 459.

25 Ibidem.

26 Pierwszy sprzeciw jednostkowy zgłosił w tej sprawie Jan Karol Romanowski, chorąży chełmski dnia 19 listopada. Wycofanie kontradykcji było konieczne dla podjęcia decyzji o prolongacie, Diariusz sejmu..., wyd. K. Przyboś, s. 32 . Dnia 29 listopada, w toku sporu o treść jednej z klauzul aktu konfederacji, przy sprzeciwie kilku województw jeden z posłów wprost wezwał marszałka do uznania sejmu za skutecznie zerwany i jego zakończenia. („Mości Panie Marszałku! Żegnaj wielmożnego jmci ks. Prymasa!’). Ostatecznie marszałek skonsultował sprawę z wszystkimi województwami i przekonał posłów mazowieckich do wycofania sprzeciwu, ibidem, s. 52.

27 Diariusz sejmu warszawskiego „convocatiey” po śmierci króla Michat, zaczętego dnia 15 stycznia a zakończonego dnia 22 lutego 1674, [w:] Dwa diariusze sejmów 1674 r. odprawionych, wyd. F. Kluczycki, Kraków 1881 s. 17.

28 Ibidem, s. 23.

29 Ibidem, s. 39.

30 Ibidem.

31 Ibidem, s. 42. 
Niezależnie od liczby posłów zgłaszających sprzeciw, relacja diariuszowa sytuuje ich zdecydowanie w mniejszości, co przy założeniu głosowania większościowego i nieuznawania jednostkowych kontradykcji, nie powinno było wpływać na losy głosowania. W tym przypadku skutkowało jednak wycofaniem projektu, zgodnie ze standardami wyznaczonymi na sejmach okresu regnum.

Rozpatrując dla porównania sejm konwokacyjny 1733 r. trudno dostrzec jakikolwiek przełom, poza może częstszym zgłaszaniem drobnych sprzeciwów, co jest charakterystyczne dla postępującej degeneracji kultury parlamentarnej szlachty polskiej w początkach XVIII w. Najistotniejszy konflikt i kryzys w trakcie tego sejmu towarzyszył rozstrzygnięciu problemu nadliczbowych mandatów niektórych województw. Okazało się bowiem, że województwa bracławskie i czernichowskie miały zbyt liczną reprezentację - po sześciu posłów, „obranych contra legem" "32. Spór zakończył się protestem posła Kazimierza Józefa Ukolskiego, podwojewodzego trockiego. Nikt z sejmujących nie miał wątpliwości, że izba poselska utraciła activitas na skutek kontradykcji. Szczególnie dramatycznie wyglądały obrady $\mathrm{w}$ dniu 7 maja, kiedy kontradycent nie pojawił się w izbie, a wysłana do negocjacji z nim deputacja, powróciwszy złożyła relację ,że nie zastali w stancyi Imć P. Trockiego, y nie mogli się dowiedzieć dokąd wyszedł". Istniała zatem realna obawa, że poseł opuścił Warszawę i dojdzie do zerwania sejmu. Dlatego członkowie deputacji dodawali uspokajająco: „,non desperandum, żeby się nie miał wrócić do Izby"33. Dopiero deputaci z kolejnego wysłanego przez marszałka kompletu ,powrócili (...) y Iemć P. Trocki z niemi” ${ }^{34}$. Przekonany już do wycofania sprzeciwu kontradycent „na swoim mieyscu zasiadłszy głos zabrał y wyraził: że lubo wszystkich królestw salus na tym dependet, aby była lex in toto, libertas in toto, widząc, że godzi się (...) uczynił był sistentiam activitas wdztwu bracławskiemu per periculossima mala, (...) aby się nie zdał

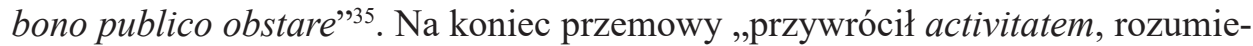
jąc, że wszyscy Ichmć magnis sensibus suis zabiegać będą inkonveniencyom"36. Widać zatem, iż przywrócenie activitatem było warunkowe. Opór kontradycenta Ukolskiego udało się co prawda załagodzić i dokonać elekcji marszałkowskiej, ale sprawę podniesiono na forum izby poselskiej jeszcze raz, blokując możliwość odbycia sesji wspólnej stanów w dniach 11 i 12 maja. Ostatecznie udało się wypracować kompromis ${ }^{37}$. Ważne jest jednak to, że w omawianej sprawie izba poselska respektowała jednostkowy sprzeciw posła z stanową procedurą obowiązującą

\footnotetext{
${ }^{32}$ B.Ossol., rkps. 6611, s. 356.

33 Ibidem, s. 356-357.

34 Ibidem, s. 357.

35 Ibidem.

36 Ibidem, s 358.

37 Ibidem, s. 377-380.
} 
na każdym innym sejmie. Nie pojawiają się jakiekolwiek argumenty z głosowania większością czy zakazem zrywania konwokacji wetem jednego posła.

$\mathrm{Na}$ tym tle widać, że przekonanie Autorki o braku możliwości zerwania konwokacji czy o stosowaniu zasady głosowania większością nie znajduje odzwierciedlenia w praktyce parlamentarnej. Co ciekawe, na samym sejmie z 1696 r., poza sprzeciwem posła Horodyńskiego, który skutkował ostatecznym zerwaniem sejmu, izba poselska już wcześniej została wprowadzona w stan passivitas przez posła Michała Kordysza. Autorka monografii nie poświęca prawnym aspektom tego wydarzenia nawet kilku zdań komentarza, poza wskazaniem, że była to pierwsza poważna protestacja na sejmie. Koncentruje się wyłącznie na przyczynie sprzeciwu posła - bytności królowej Marii Kazimiery w Warszawie ${ }^{38}$. Szkoda, bo epizod ten jest nadzwyczaj znamienny dla analizowanego problemu. Znów mieliśmy tu do czynienia ze standardową dla liberum veto sytuacją - koniecznością podjęcia decyzji o prolongowaniu obrad. Dnia 12 września poseł Kordysz w mocnych słowach zgłosił kontradykcję. Zapowiadał poinformowanie swoich „braci” na sejmiku o winie obecnej w Warszawie królowej w niedojściu sejmu, po czym wyszedł z izby. Podstawowym zadaniem marszałka sejmu Stefana Humieckiego i wspierających go senatorów stało się oczywiście zapobieżenie opuszczeniu przez posła-kontradycenta stolicy. Należało w pierwszej kolejności przekonać go choćby do podjęcia rozmów o powro$\mathrm{cie}^{39}$. Kluczową rolę odgrywał tu sam marszałek poselski, według najbardziej wiarygodnej wersji to on sam, osobiście, pobiegł za posłem, żeby go zatrzymać. Humiecki osiągnął tu sukces, który pozwolił na dalsze trwanie sejmu: „dogonił [kontradyceta Kordysza - T.K.] ImP Maraszałek poselski, ale nie chciał się [on] wrócić chyba cum hac praecustodine ieśli iutro wydzie declaracya od królowey Jemci że ustąpi z Warszawy"40. Sytuacja była więc uratowana. Poseł stawiał warunki, a zatem prowadził dialog. Jego postanowienie zerwania sejmu nie było definitywne, był gotów do powrotu w przypadku spełnienia jego żądań. Rozpoczynało to żmudną procedurę negocjacji, której nie dało się przeprowadzić tego samego dnia, szczególnie w emocjonalnej atmosferze. Posłowie, choć pozostawieni w stanie passivitas podjęli decyzję o zgodzie na wyznaczenie sesji „ostatniej szansy”, na dzień następny. Użyto tu instrumentu limity, skoro sesji nie można było prawidłowo prolongować - w relacji z obrad zanotowano: „dlatego limitowana sessya (...) in spem powrócenia się iutro tegoż pana

${ }^{38}$ E. Gąsior, op.cit., s. 208-210.

39 Jednak z relacji donosiła, że „Protestator wyszedł, którego kiedy goniono, obiecał przywrócić activitatem byle królowa ustąpiła”, B.Ossol., rkps. 652, k. 23.

${ }^{40}$ Ibidem. 
Kordysza" ${ }^{41}$. Dnia 13 września marszałek poselski postanowił zastosować dość nieortodoksyjną metodę - wysłał do Kordysza drugiego z posłów czernichowskich uznając, że temu uda się łatwiej przekonać współziomka. Po powrocie poseł powtórzył jednak zdanie swojego „collegi” z dnia wczorajszego - kontradycent obiecał, że przywróci activitas i zgodzić się na prolongację obrad, jeśli jego żądania zostaną spełnione ${ }^{42}$. Uznano to za postęp w negocjacjach, jednakże prawo zwyczajowe dotyczące liberum veto było już silnie utrwalone i activitas mogła zostać przywrócona tylko przez posła osobiście. Jego powrót i dokonanie przez niego osobiście oficjalnego wycofania sprzeciwu były zatem nieodzowne. W konsekwencji „niekontenci byli PP posłowie wielkopolscy”, co spowodowało, że wszyscy uczestnicy obrad ,urgentes aby Im P. Kordysz in sua persona restituat activitatem nie przez collegę"43. Sięgnięto zatem do standardowego instrumentu - marszałek mianował trzyosobową deputację, która miała udać się na stancję i przekonać posła do powrotu. Jej również udało się jednak tylko uzyskać deklarację zaoczną o warunkowym przywróceniu activitatem izbie. Poseł jednak uległ silnej presji, pojawił się na obradach w dniu następnym, tj. dnia 15 września. Początkowo wycofał sprzeciw tylko na czas przyjęcia poselstwa od wojska. Dopiero po zakończeniu tej audiencji, prawdopodobnie dla lepszego efektu propagandowego, zabrał głos i definitywnie cofnął swój sprzeciw, wyrażając zgodę na prolongację obrad ${ }^{44}$.

Analogicznie wyglądał sprzeciw posła Horodyńskiego, który ostatecznie doprowadził do zerwania sejmu. Znamienne, że mimo niewątpliwej precedensowości zerwania konwokacji, diariusze poświęcają temu właśnie sprzeciwowi znacznie mniej uwagi niż kontradykcji Kordysza. Jest to w pełni logiczne, sejm był już wielokrotnie prolongowany, skala sporów ogromna, napięcia silne. Doświadczeni posłowie i senatorowie oraz obserwatorzy życia publicznego byli w stanie nie-

${ }^{41}$ Według innej wersji ,solwowanie” po proteście posła Kordysza nastąpiło „in spem reditu powrótu jego", Diariusz Prawdziwy, bo bez imienia autora wszystkich rzeczy i dziejów, które w Polsce się działy od śmierci Jana III króla polskiego aż do obrania Augusta II (z rękopisu spółczesnego), [w:] L. Rogalski, Dzieje Jana III Sobieskiego, króla polskiego, wielkiego księcia litewskiego, Warszawa 1847, s. 422.

42 „Declaracya zaś taka była przez college p. Kordysza (...) iako wczoraj z ust samego tegoż p. protestanta ieśli Królowa IeMć ustąpi o powróci activitatem y tenże Jemć p.poseł brcławski collega moy", Archiwum Główne Akt Dawnych [dalej: AGAD], Archiwum Radziwiłłów [dalej: AR], dz. II, rkps. 33, s. 335.

43 Ibidem.

44 „Skończywszy audiencyą miał głos P. Kordysz Poseł Bracławski. Prostestant daiąc rationem wyiścia swego (...) iako y teraz urgendo wyjazdu Królowey Jemci sistit do iutra activitatem", AGAD, AR II-33, s. 336; „wziął głos pan Gordyusz [sic! - TK] y dał racyą zabraney activitatis, którą potym pozwolił, in fundamento deklaracyey, że królowa Iemć wyiedziek", B.Ossol., rkps. 652, k. $23 \mathrm{v}$. 
omylnie rozpoznać sygnały, że sejm nie dojdzie do skutku. Stąd brak zaskoczenia, kiedy to w końcu nastąpiło. Odwoływanie się do prawa wolnego sprzeciwu obecne jest w trakcie obrad sejmowych przez cały czas ich trwania ${ }^{45}$.

W każdym z powyżej wskazanych przypadków widzimy zupełnie standardową procedurę zgłaszania jednostkowych sprzeciwów, charakterystyczną dla staropolskich sejmów walnych. Poseł zgłasza protestację i wychodzi. Marszałek, czasem z pomocą innych osób, stara się zapobiec przede wszystkim wyjazdowi kontradycenta $z$ Warszawy. Jeśli się to uda, prowadzone są z nim negocjacje, z reguły za pośrednictwem poselskiej deputacji. Activitas izby zostaje przywrócona w sytuacji, gdy poseł wróci do sali obrad i formalnie cofnie swój sprzeciw, co skutkuje oczywiście kontynuowaniem prac sejmu. W przeciwnym razie sejm trwa (ale tylko z głosem pasywnym) dopóty, dopóki będzie istniała realna nadzieja powrotu posła. Jeśli nadzieja ta zgaśnie, marszałek za zgodą pozostałych posłów uznaje sejm za zakończony i dopełnia ceremoniałów końcowych. Nie ma tu symptomów odmienności reguł obowiązujących na sejmach konwokacyjnych, w porównaniu do sejmów okresu regnum. Nie ma śladu jakiegokolwiek świadectwa źródłowego, które wskazałoby, że w praktyce konwokacje były uważane za zgromadzenia „niezrywalne” tudzież respektujące regułę podejmowania decyzji większością głosów.

Warto zauważyć, że krytyka kontradykcji i faktu zerwania sejmu z 1696 r. nie jest zresztą, wbrew sugestiom Autorki, szczególnie gwałtowna. Rytualne uznawanie faktu zerwania sejmu za „,skandaliczne” i „nieszczęśliwe”, przy jednoczesnym obarczaniu winą przeciwników politycznych było w 2. poł. XVII wieku powszechne ${ }^{46}$. Wydaje mi się, że nie ma dowodów na to, że oburzenie z roku 1696 było w jakiś sposób wyjątkowe, poza może podkreślaniem szczególnych okoliczności - okresu bezkrólewia. Nie odwoływano się tu jednak do poglądu o nielegalności takiego działania posła. Argumentacja jest typowo polityczna - Rzeczpospolita bez króla znajduje się zawsze w szczególnym niebezpieczeństwie, a więc zerwanie sejmu w tym czasie jest bardzo niebezpieczne.

Niniejszy szkic nie może oczywiście zastąpić szczegółowego, poświęconego konwokacjom studium monograficznego z uwagi na ograniczoną długość tekstu i niepełny materiał źródłowy. Wydaje mi się jednak, że powyższe rozważania dostatecznie udowadniają tezę, że w praktyce parlamentarnej dawnej Polski, wbrew tezom Autorki monografii, nie było uznania dla reguły głosowania większością głosów i prawnego zakazu zrywania konwokacji. Pozostaje zatem poddać wery-

${ }^{45} \mathrm{~Np}$. jeden z posłów w dniu 7 września powiedział ,iam szlachcic mam vocem vetandi za czym y teraz prostestuję", ibidem, k. 20.

${ }^{46} \mathrm{O}$ negatywnym stosunku do mnożących się kontradykcji za opanowania Jana III Sobieskiego szeroko pisze R. Kołodziej, op.cit., s. 449-450. 
fikacji założenia ogólne, które legły u podstaw tych twierdzeń - tezy o skonfederowaniu konwokacji.

\section{KONWOKACJA A VINCULUM CONFOEDERATIONIS}

Punktem wyjścia jest dla Autorki założenie, obecne w istniejącej już literaturze, że konwokacja była sejmem odbywanym pod węzłem konfederacji, czyli formą sejmu skonfederowanego ${ }^{47}$. Brakuje tu jakiejkolwiek argumentacji, poza wskazaniem odwoływania się w debacie publicznej dawnej Polski do pewnego skrótu myślowego, określającego konwokację (a raczej jej uchwały) mianem konfederacji (a raczej aktu konfederacji). Jest to raczej słaby argument, szczególnie biorąc pod uwagę charakterystyczny dla Rzeczypospolitej brak precyzji terminologicznej, zwłaszcza w ramach języka prawnego i prawniczego. Ogólna koncepcja konfederacji staropolskich w pracy E. Gąsior nie jest zresztą koherentna, Autorka prezentuje bardzo niekonsekwentny zestaw twierdzeń w tym zakresie w różnych częściach książki ${ }^{48}$.

Zgodnie z niewykorzystanymi niestety przez Autorkę monografii szerokimi wyjaśnieniami Wojciecha Stanka, konfederacje szlacheckie powoływano oddolnie na poziomie województwa ${ }^{49}$. Następnie przedstawiciele konfederacji lokal-

${ }^{47}$ Jest to pogląd rozpowszechniony, powiela go nawet W. Stanek, op.cit., s. 191.

${ }^{48} \mathrm{~Np}$. co do dyskusji na forum izby poselskiej w dniu 12 września Autorka wyraźnie wskazuje, że przedmiotem dyskusji było „zawiązanie konfederacji”, E Gąsior, op.cit., s. 196. Jak można było dyskutować nad zawiązaniem istniejącego już węzła konfederackiego? W innym miejscu, przy omówieniu elekcji marszałkowskiej, Autorka komentuje relację K. Jarochowskiego (Dzieje panowania Augusta II, t. I Od śmierci Jana III od śmierci Jana III do chwili wstapienia Karola XII na ziemię Polska, Oświęcim 2015, s. 30), który przytaczał i oceniał opinię referendarza koronnego Kazimierza Szczuki. Niestety Autorka przekręca sens cytowanej wypowiedzi. Pisze bowiem: „referendarz wnioskował, »aby dla łatwiejszego rozwiązania obecnej trudności sejm obecny jako konfederację uważać«, a więc marszałkiem obrać tego, który uzyska większość głosów”, E. Gąsior, op.cit., s. 170. Wiąże więc Autorka tę propozycję z głosowaniem większością głosów. Ze zdziwieniem konstatuje przy tym, że projekt ten odrzucono, co trudno powiązać z jej późniejszymi rozważaniami, że sejm był faktycznie skonfederowany. Najważniejsze jest jednak to, że opinia Szczuki przytaczana przez Jarochowskiego wcale nie odnosiła się do konfederowania sejmu. Nie dotyczyła ona również samego głosowania większością. Autorka nie zauważyła, że wybór marszałka sejmowego większością głosów przez kreskowanie był przyjętym sposobem wyboru na w zasadzie każdym sejmie i nie trzeba było do niego jakiegoś konfederowania. Referendarz odwołał się tu, na zasadzie analogii, do reguł konfederacyjnych, bo chciał wykorzystać fakt, że walne rady konfederacyjne nie znały alternaty laski marszałkowskiej między Małopolską, Wielkopolską i Litwą. Reguła ta obowiązywała bowiem wyłącznie na sejmach walnych. W ten sposób możliwe byłoby rozładowanie zaistniałego sporu o alternatę. Projekt odrzucono jednak właśnie dlatego, że konwokacja była sejmem, a nie walną radą konfederacką. Obowiązywały więc na niej sejmowe reguły, z których nie można było zrezygnować.

${ }^{49}$ W. Stanek, op.cit., s. 45. 
nych na konwokacji w bezkrólewiach, a na specjalnym zjeździe zwanym walną radą w okresach regnum, podejmowali uchwałę (naturalnie jednomyślnie!) o zawiązaniu konfederacji generalnej, czyli ogólnokrajowej ${ }^{50}$. Z formalnego punktu widzenia uchwała powołująca związek szlachty nosiła nazwę aktu głównego konfederacji $i^{51}$.

Podkreślam te fakty z zupełnie prozaicznego powodu. Otóż oczywistym jest, że żeby zawiązać węzeł ogólnopolskiej konfederacji potrzeba aktu konfederacji, przyjętego na szczeblu centralnym - co udowodnił Stanek - jednomyślną uchwałą. Akt konfederacji na konwokacjach uchwalano tak, jak standardowe konstytucje sejmowe - na sam koniec zgromadzenia, na sesji wspólnej stanów w senacie, zwanej konkluzją. Całość prac ustawodawczych wieńczyło posejmowe „ucieranie" aktu na „sesji pieczętarskiej” "52. Zasadniczą odrębnością od standardowego procesu legislacyjnego był tu fakt składania podpisów pod aktem przez wszystkich senatorów i posłów. Zgodnie z utartą tradycją znaczna część, jeśli nie większość sejmujących dopisywała przy tym zastrzeżenia do treści aktu ${ }^{53}$.

Skoro akt konfederacji, którym powoływano konfederację ogólnokrajową, stanowił rezultat końcowy prac konwokacji, to zgodnie z logiką dopiero efektywne zakończenie prac przez ten sejm oznaczało powstanie generalnego węzła

${ }^{50}$ Istnienie konfederacji lokalnych nie było wymagane w sytuacji, w której konfederację generalną powoływał do życia ogół szlachty, zebrany na walnym zjeździe w trybie pospolitego ruszenia, jak np. zjazd pod Gołębiem w 1672 r.

${ }^{51}$ Wychodząc od refleksji Stanka musimy stwierdzić, że skoro konwokacja była sejmem - tj. organem reprezentacyjnym, potrzebowała uprzednich aktów konfederacji lokalnych - podejmowanych przez sejmiki kapturowe. Co prawda - wbrew twierdzeniom E. Gąsior - nie wszystkie sejmiki przedkonwokacyjne były odbywane w formie zjazdów konfederacji. Niektóre zwyczajowo zawierały swoje konfederacje lokalne dopiero na samym sejmie konwokacyjnym albo po nim, na podstawie upoważnienia zawartego w treści aktu konfederacji generalnej: „które ieszcze województwa (...) kapturów, laudów swych przed konwokacyą nie maiąc, tu ie sobie na tey konwokacyi za braci swey zlecieniem uczynili, y które ieszcze na seymikach swoich, po konwokacyi pierwszych, postanowić ie sobie będą chciały, tedy im wolno. A te Kaptury vigore preasentis Conventus et approbationis nostrae, takąż też moc mieć będą, iako y insze przed konwokacyą uczynione”, VL, t. III, s. 347, fol. 727; t. IV, s. 76, fol. 154; s. 486, fol. 1032; t. V. s. 113, fol. 205.

${ }^{52}$ Relację o odbywaniu po konwokacji standardowych sesjach pieczętarskich przekazuje marszałek z 1668 r. - J.A. Chrapowicki, op.cit., s. 464-465.

${ }^{53}$ Autorka nie odnosi się do poprzednich aktów konfederacji uchwalanych na konwokacjach, jej wywody sprawiają wrażenie - z gruntu błędne - że sam fakt składania salw był wyjątkowy właśnie dla okoliczności konwokacji z 1696 r. A przecież były one składane zawsze, różniła je tylko treść. Towarzyszyły one również innym aktom, szczególnie paktom konwentom, szerzej na ten temat zob.: T. Kucharski, Czynności i uchwały sejmów elekcyjnych w Rzeczypospolitej Obojga Narodów w latach 1632-1733, rozprawa doktorka obroniona na Wydziale Prawa i Administracji UMK pod kierunkiem naukowym Zbigniewa Naworskiego, Torun 2017. W dalszym toku analizy będę się do tych asekuracji często odwoływał. Zawierają one bowiem bardzo interesujący zestaw argumentów prawnych, ważnych dla wyjaśnienia fenomenu zerwania konwokacji i uchwalenia mimo tego aktu konfederacji. 
konfederacyjnego ${ }^{54}$. To właśnie wyrażała słynna mowa wygłoszona po zerwaniu konwokacji z 1696 r. przez Jana Odrowąża Pieniążka. Zgodnie z jego opinią posłowie zjechali się na konwokację tylko z ,intencyą aby partikularne confoederacye które po woiewództwach stanęły w zgromadzeniu generalnym Rzpltey in unam massa generalney confoederacyey złączone były na zaszczyt wolney electiey na utrzymanie praw dawnych Rzpltey na uprzątnienie wszystkich exorbitancyi (...). Aby securitati internae et externae były provisum" ${ }^{55}$. Skoro zatem podstawowym założeniem konwokacji było doprowadzenie do powołania konfederacji do życia, to taż konfederacja nie mogła już istnieć w momencie jej rozpoczęcia i w czasie jej trwania. Sejm konwokacyjny nie mógł się zatem odbywać sub vinculo confoederationis, albowiem takowego węzła jeszcze nie było ${ }^{56}$. Miał on dopiero powstać w wyniku zakończenia prac sejmu i powzięcia stosownej uchwały. Istniały co najwyżej „węzełki” lokalnych konfederacji, wiążące jedynie szlachtę danego sejmiku, w celu zapewnienia ładu i bezpieczeństwa w okresie bezkrólewia. Widać to $\mathrm{w}$ arcyciekawym, a niewyłuskanym przez Autorkę z treści diariuszy, głosie posła Hieronima Krasuskiego [Krasuckiego], burgrabiego krakowskiego, który wskazał, że „mamy w confoederacyach naszych, że pro hoste patriae ma reputari ten co rwie convokacyą" ${ }^{57}$. Poseł wskazuje, że jego sejmik kapturowy nakazuje traktować jak wroga ojczyzny, a więc sprawcę crimen perduellio osoby, która ośmieliłaby się zerwać sejm konwokacyjny. Problem polegał na tym, że moc tego zobowiązania była skuteczna tylko względem szlachty, która jednomyślnie przyjęła je na siebie, a zatem skonfederowanej szlachty województwa krakowskiego. Innych uczestników sejmu ten punkt lokalnej instrukcji sejmikowej nie wiązał z formalnoprawnego punktu widzenia. Poseł nie powołał się tu ani na regułę skonfederowania konwokacji, ani na ugruntowaną normę prawną zakazującą zrywania sejmów tego typu, bo takowych po prostu nie było. Argumentem,

${ }^{54}$ Przyznaje to w zasadzie, choć niechętnie - W. Konopczyński, Liberum veto..., s. 264 i n., który wskazuje, że niezrywalność konwokacji z uwagi na jej powiązanie z zawiązywaniem węzła konfederacji była oryginalną interpretacją stronnictwa Czartoryskich, sformowaną w roku 1764. Oczywiście podejmuje przy tym próbę obrony stanowiska, według którego zerwanie konwokacji 1696 r. było w zasadzie niedopuszczalne (nazywa ten akt „fałszywym precedensem”, ibidem, s. 267).

${ }^{55}$ Lwowska Naukowa Biblioteka im. W. Stefanyka NAN Ukrainy. Oddział rękopisów [dalej cyt. LNB], z. 4, rkps. 66, k. $187 \mathrm{v}$.

${ }^{56}$ Skąd teza H. Olszewskiego [op.cit., s. 429], że obrady konwokacji z 1674 r. toczyły się „przez prawie 6 tygodni, w tym większość pod konfederackim vinculum”, trudno dociec. Autor nie zamieścił przy tej informacji przypisu. Ze znanych mi diariuszy zawiązanie konfederacji w trakcie sejmu, przed przyjęciem samego aktu konfederacji absolutnie nie wynika, por. m.in. Diariusz seymu..., [w:] Dwa diariusze..., wyd. F. Kluczycki, s. 3-43; B.Ossol., rkps. 247, k. 331-364.

${ }^{57}$ AGAD, AR, II-33, s. 363. 
do którego się odwołał, była tylko aktualna wola szlachty skonfederowanej lokalnie, wyrażona w partykularnej instrukcji.

Wyprzedzając nieco dalszą analizę warto wskazać, że dlatego właśnie nie próbowano wyciągać względem posła Horodyńskiego - kontradycenta, który zerwał sejm - żadnych konsekwencji prawnych. Jeśli już, to postulowano postawienie przed wymiarem sprawiedliwości jego mocodawców czy zleceniodawców, ale jako osób korumpujących posła ${ }^{58}$. Argumenty tego typu, powszechne zresztą w debacie publicznej Rzeczypospolitej owego czasu, nie odnosily się wcale do nielegalności samego protestu czy złamania zobowiązania wynikającego z ogólnokrajowej konfederackiej przysięgi i generalnego konfederackiego węzła.

Dopiero w tym kontekście możliwe jest prawidłowe zrozumienie refleksji J.O. Pieniążka (o relacji konwokacji i konfederacji), której Autorka poświeciła niestety tylko trzy zdania. Szkoda, bo ta opinia stanowi zestaw podstawowych argumentów kwestionujących zgodność z prawem wydania aktu konfederacji bez jednomyślnej zgody sejmu konwokacyjnego, który został skutecznie zerwany jednostkowym sprzeciwem. Głos Pieniążka można przy tym uznać za klarowną wykładnię poglądów prawnych na same bezkrólewiowe konfederacje generalne. Twierdził on, że konwokacja i konfederacja są ze sobą powiązane i nie można ich rozdzielić ${ }^{59}$. Co to oznaczało? Przede wszystkim stwierdzenie nielegalności forum i procedury zawiązania ogólnokrajowej konfederacji w 1696 r. Zdaniem Pieniążka tylko na skutecznie zakończonej i jednomyślnej konkluzji sejmu konwokacyjnego mogło dojść do uchwalenia aktu konfederacji, który z kolei skutkował zawiązaniem węzła konfederacji generalnej. Żaden inny organ państwowy nie mógł takiego aktu uchwalić, a więc takiego węzła zawiązać. W konsekwencji zerwanie konwokacji musiało w rezultacie oznaczać niemożność uchwalenia aktu konfederacji (i stawało na przeszkodzie zawiązaniu konfederackiego węzła). To prosta i klarowna argumentacja prawnicza, jasno wyjaśniająca podstawowy problem prawny, który stanął przed elitą polityczną Rzeczypospolitej w $1696 \mathrm{r}$. To ten pogląd - jako modelowy - powinien był stanowić dla Autorki punkt wyjścia do dalszych rozważań o tym, jak doszło do ostatecznego uchwalenia aktu konfederacji w 1696 r. Tylko prawidłowe zrozumienie tej tezy pozwoli pojąć, jaka była alternatywna interpretacja prawna, która ostatecznie posłużyła do uzasadnienia legalności przyjęcia aktu konfederacji, mimo uznania skuteczności zerwania sej-

${ }^{58}$ Przedmiotem oskarżeń opinii publicznej była w tym kontekście głównie królowa-wdowa, Maria Kazimiera Sobieska - por. m.in.: W. Konopczyński, Liberum veto..., s. 277; M. Komaszyński, Maria Kazimiera d'Arquien Sobieska. Królowa Polski 1641-1716, Kraków 1983, s. 187. A. Czarniecka, Królowa wdowa w polityce. Pozycja Marii Kazimiery po śmierci Jana III (1696-1697) [w:] A. Kalinowska, P. Tyski (red.), Maria Kazimiera Sobieska (1641-1716): w kręgu rodziny, polityki i kultury, Warszawa 2017, s. 156.

59 To zdanie z mowy Pieniążka cytował również H. Olszewski, op.cit., s. 427. 
mu konwokacyjnego. Kontekst polityczny sprawy jest niemożliwy do prawidłowego opisania bez rekonstrukcji poglądów prawnych.

\section{UZNANIE SPRZECIWU HORODYŃSKIEGO}

\subsection{Aspekt doktrynalny}

Rekapitulując poglądy Ewy Gąsior na zerwanie konwokacji w 1696 r. należy raz jeszcze przypomnieć, że jej zdaniem konwokacji nie można było zerwać, bo była sejmem skonfederowanym. Sejm taki miał nie dopuszczać skutecznego prawnie zgłaszania jednostkowych sprzeciwów. Mimo to marszałek i posłowie zaakceptowali taki bezprawny sprzeciw i w ten sposób zalegalizowali zerwanie sejmu.

Jak wskazałem powyżej, argumentacja o odbywaniu sejmu pod węzłem konfederacji nie wytrzymuje krytyki, podobnie jak teza o istnieniu formalnego zakazu zrywania konwokacji. Pozostaje nam do zinterpretowanie jeszcze jedno twierdzenie, mianowicie, że formalnie niedopuszczalne zerwanie konwokacji stało się możliwe na skutek jego wyjątkowego, jednorazowego „uznania” przez konkretny skład sejmujących. Przede wszystkim warto zwrócić uwagę na fakt, że zjawisko „uznania sprzeciwu”, które Autorka zdaje się traktować jako zupełnie unikatowe, było w rzeczywistości zupełnie standardową procedurą (usankcjonowaną prawem zwyczajowym). Regulowała ona sposób zgłaszania sprzeciwu, mechanizm starań na rzecz cofnięcia protestu i w końcu konsekwencje fiaska tych inicjatyw. Każdy sprzeciw na każdym sejmie wymagał dla swej skuteczności „uznania” go przez marszałka i posłów ${ }^{60}$.

W kompletny i trafny sposób charakteryzuje staropolskie kontradykcje G. Lengnich. Pisze on w omawianym kontekście:

${ }^{60}$ Zdarzały się oczywiście przypadki wywierania presji na kontradycentów, zmuszanych do cofnięcia sprzeciwu albo wprost lekceważenia poprawnie zgłoszonych sprzeciwów. Ciekawe refleksje na temat możliwości kwestionowania poselskich sprzeciwów zawarł w swoim studium R. Kołodziej, op.cit., s. 436-422. W praktyce możemy zauważyć, że np. w 1658 r. na sejmie pominięto milczeniem protest arianina - Tobiasza Iwanickiego, przeciwko konstytucji o wygnania przedstawicieli tego wyznania z Rzeczypospolitej. Oczywiście wiązało się to z faktycznym pozbawieniem go mandatu poselskiego, ale bez podstawy prawnej i bez formalnego wyrugowania go z izby, por. J.W. Wołoszyn, Problematyka wyznaniowa $w$ praktyce parlamentarnej Rzeczypospolitej w latach 1648-1696, Warszawa 2003, s. 142-143. W trakcie walnego zjazd rokoszu łowickiego w 1698 r. próba zerwania obrad jednostkowym sprzeciwem przez Aleksandra Chlebowskiego, spotkała się z wykpieniem przez zebraną szlachtę, a w końcu groźbami, które zmusiły posła do wycofania kontradykcji. W. Stanek, op.cit., s. 46-47. Były to jednak sytuacje wyjątkowe i usprawiedliwiane jakimiś pretekstami prawnymi, albo presją faktyczną. Nie było to kwestionowanie zasady unanimitas. 
nie każdy jednak opór [tj. sprzeciw posła - TK] zerwanie sejmu za sobą pociąga, lecz niekiedy wstrzymuje tylko bieg sejmu, co mianowicie u nas ,sistere activitatem" się nazywa. Następnością takiej przerwy jest, iż przez ten czas nic stanowionem, ani też skutecznie roztrząsanem być nie może, lecz objawiane zdania biernemi tylko, nie zaś stanowczemi są zwane, i do tego zmierzają, aby przeciwników złagodzić, i pobudzić do ustąpienia w uporze ${ }^{61}$.

Sam sprzeciw nie jest zatem samodzielnym faktem prawnym skutkującym zerwaniem obrad ipso iure. Marszałek poselski i posłowie mieli prawo reagowania na ten fakt i korzystali z niego próbując zapobiec zerwaniu sejmu, co pokazywałem już powyżej na przykładzie praktyki. W rezultacie sejm zostawał zerwany dopiero wtedy, kiedy marszałek i posłowie „uznali” skuteczność sprzeciwu, tzn. skonstatowali brak jakichkolwiek perspektyw dla jego cofnięcia ${ }^{62}$. Lengnich wyraźnie zaznacza, że sam protest nie oznaczał automatycznego rozejścia się sejmu: „podobne przerwanie działalności, na jednym sejmie kilka razy, z powodu jednego lub kilku posłów wydarzyć się może”. Dopiero w sytuacji, w której kontradycent trwa „nie ugięty w swym zdaniu”, a zwłaszcza gdy ,z miejsca sejmu wyjedzie, sejm tedy przepada". Sprzeciw ten musi być jednak zawsze potwierdzony, czyli „uznany” przez marszałka za zgodą posłów, co skutkowało dokonaniem czynności zamykających obrady sejmowe: „o zerwaniu sejmu marszałek poselski z żalem królowi i senatowi (...) donosi, prosi, aby do ucałowania ręki przystąpić było wolno"63.

Taki obraz wyłania się z opisanych powyżej przypadków zgłaszania protestów na konwokacjach. Oczywistym jest zatem, że konwokacja w 1696 r. musiała zostać formalnie uznana za zerwaną, był to naturalny skutek zastosowania ius vetandi.

\subsection{Aspekt praktyczny - postawa marszałka Humieckiego}

${ }^{61}$ G. Lengnich, op.cit., s. 374.

${ }^{62}$ Towarzyszyła temu utarta procedura działania: ,wtenczas marszałek poselski, przeciwnika [tj. osobę składającą kontradykcję - TK] na zbawienie Rzptej, na miłość ojczyzny zaklina, aby obrad nie wstrzymywał; a do próśb jego przyłączają się i posłowie, i senatorowie, jeśli w ich przytomności sprzeciwienie się nastąpiło. Jeżeli sprzeciwiający z Izby Poselskiej lub z Senatu odejdzie, tedy do mieszkania jego przychodzą członkowie z izby z prośbami, a gdy ich zabiegi są próżne, po drugi raz jeszcze wysyłani bywają". Starania marszałka mogły przynieść pozytywne efekty w postaci powrotu posła i przywrócenia sejmowi zdolności do podejmowania skutecznych prawnie uchwał ,gdy się wreszcie nakłoni i do izby powróci, przyjmują go tam z pochwałami i dziękczynieniem i obrady znów są dalej ciągnione (...). Przywraca ją [activitas - TK] zaś wprost lub pod warunkiem; którego więc wprzód dopełnić należy", ibidem, s. 375.

${ }^{63}$ Ibidem, s. 375. 
Konsekwencjami sprzeciwu Horodyńskiego stały się: przyjęcie aktu konfederacji oraz, wyeksponowane przez Ewę Gąsior w osobnym akapicie, złożenie pod nim podpisów z salwami. Szczególnie dużo miejsca Autorka poświęciła przy tym charakterystyce postawy marszałka izby poselskiej, wskazując, że Humiecki odmówił podpisania aktu jako marszałek izby poselskiej. Niestety Autorka nie stara się nawet wyjaśnić jego postawy, a argumentacja, do której się odwołuje, jest chaotyczna. Szkoda, bo odpowiednia ocena stosunku marszałka do aktu mogłaby rzucić znakomite światło na charakter prawny jego przyjęcia.

Autorka nie dość dokładnie prześledziła relacje diariuszy. Zacytowała bowiem i zinterpretowała niepełny fragment najszerszej relacji dotyczącej tego problemu. W całości brzmi ona tak: „odpowiedział P. Marszałek poselski, że Iuramentum wykonał explicite od posłów mieć dependencją (...)”. Dalej tłumaczył: „Za czym excusować się $\mathrm{w}$ tym muszę, iż przysięga moia iest de tenore tali, to iest abym trzy razy pytał się wprzód. Iż się podpiszę ieżeli powszechna zgoda na to. Dopiero kiedy nam P. Horodyński Poseł Czernichowski wyszedłszy od nas z contradictia wziął activitatem nie mogę tego uczynić". Po tych słowach marszałek wypowiedział zacytowane przez Ewę Gąsior słowa: „chybabym sobie tego życzył, żeby mię palcem ukazywano, że na tym marszałku wolność polska szyję złamała" ${ }^{64}$. Humiecki powoływał się wprost na obowiązek wynikający z marszałkowskiej przysięgi, która również nie została szeroko zanalizowana przez Autorkę, ani w omawianym kontekście, ani w ogóle ${ }^{65}$.

Co istotne, inna relacja diariuszowa uzupełnia dodatkowo tę wypowiedź marszałka, miał bowiem według niej zakończyć swoją mowę słowami: „podpisać [aktu konfederacji - T.K.] iako marszałek konwokacyalny nie mogę. Co zaś do confoederacyey ta iest potrzebna y powinna być podpisana koniecznie y ia ią approbo" ${ }^{" 66}$. Humiecki wyrażał swoje przekonanie o konieczności przyjęcia aktu konfederacji, odmawiał jednak swojego podpisu z uwagi na sejmową procedurę i złożoną przez siebie marszałkowską przysięgę, której niedotrzymanie groziło mu odpowiedzialnością (również karną). Poświęciłem tej sprawie dużo miejsca, bo ma ona kluczowe znaczenie dla zrozumienia postawy marszałka Humieckiego i prawidłowego zinterpretowania jego wypowiedzi.

${ }^{64}$ AGAD, AR, II-33, s. 371-372.

${ }^{65}$ Znamienne, że Autorka omawiając wybór Humieckiego nie wspomina o złożeniu przez niego przysięgi, E.Gąsior, op.cit., s. 172-173. Informują o tym fakcie diariusze, por. m.in.: B.Ossol., rkps. 652, k. 20v; AGAD, AR, II-33, s. 315.

${ }^{66}$ Problemowi przysięgi najwięcej uwagi poświęciła S. Ochmann-Staniszewska, Przysięga marszatka poselskiego na sejmach z lat 1648-1668. Ostatecznie rotę przysięgi zawiera konstytucja sejmu z 1678 r., VL, t. V, s. 267, fol. 546-547. Marszałek przysięgał przede wszystkim, że ,żadney konstytucyi, na którąby iaka zaszła kontradykcya, o którą trzy kroć spytać się powinien będę in Volumen Legum nie podam, y nie wpiszę". Na rotę właśnie w takim kształcie powoływał się Humiecki. 
Niepoprawna ocena analizowanej wypowiedzi marszałka doprowadziła Ewę Gąsior do prawniczo błędnej w samej swej istocie konkluzji, że Humiecki „złożył" laskę marszałkowską, przez co miał przestać być marszałkiem poselskim i uczestniczyć w dalszych pracach sejmu już tylko jako szeregowy poseł ${ }^{67}$. Błąd polega tu na niepoprawnej interpretacji pojęcia „złożenia laski” marszałkowskiej, które nie oznaczało wcale zrzeczenia się czy rezygnacji z funkcji marszałka ${ }^{68}$. Należy uznać, że był to raczej ceremonialny akt oznaczający formalne zamknięcie obrad w izbie poselskiej, towarzyszący decyzji o pójściu posłów „na górę”, czyli do izby senatorskiej w celu odbycia konkluzji ${ }^{69}$.

Marszałek Humiecki użył omawianej frazy pragnąc stwierdzić zamkniecie obrad na skutek sprzeciwu, a nie rezygnację z funkcji. Skutkiem prawnym tak rozumianego „złożenia laski” było zatem zamknięcie obrad sejmu, a więc również pełne wygaśniecie „czynnego" mandatu posłów do podejmowania uchwał w izbie poselskiej. W takiej sytuacji ani szeregowy poseł, ani dyrektor izby nie mogli wykonywać w sensie ścisłym swoich zadań, wynikających z mandatu. Nie mogli zatem np. zebrać się ponownie w tym samym składzie i uchwalić jakichś konstytucji. Co ważne, na tym etapie zarówno marszałek, jak i posłowie zachowywali status „marszałka” i „posłów”, tyle że sejmu zakończonego. Tego zaś statusu nie można było się zrzec ani go utracić. W związku z tym - co do zasady - byli marszałkowie i byli posłowie musieli wykonać pewne obowiązki formalnie z tego

${ }^{67}$ „Był już tylko jednym z posłów, a nie przewodniczącym izby poselskiej”, E. Gąsior, op.cit., s. 233-234. Sugeruje to jakąś formę zrzeczenia się czy wygaśnięcia funkcji marszałka, przy jednoczesnym trwaniu mandatu poselskiego już po formalnym zamknięciu obrad sejmu.

${ }^{68}$ Laska była wyłącznie symbolem czy też oznaką właściwej władzy marszałka, por. W. Maisel, Archeologia prawna Polski, Warszawa - Poznań 1982, s. 235-236. W konsekwencji używano jej często na określenie władzy urzędu, a nie przedmiotu. Marszałek obejmował urząd „,przyjmując laskę”, którą marszałek poprzedni „oddawał”. Podobnie marszałek wzywający posłów nakazywał im ,przyjść pod laskę”. Według tych samych reguł, gdyby Humiecki chciał się zrzec godności, „oddałby” laskę izbie albo swojemu następcy, a nie ją „złożył”. Musiałby zresztą poprosić o zgodę sejmujących na rezygnację, czego nie zrobił. Nie ma oczywiście w relacjach diariuszowych informacji o przekazaniu władzy przez Humieckiego jakiemukolwiek innemu marszałkowi. Nie przytacza takich danych także Ewa Gąsior. A przecież jakiekolwiek obrady sejmowe bez przewodniczącego były niedopuszczalne. Reguły prawa zwyczajowego przewidywały zastępstwo marszałków sejmowych w nagłych wypadkach, por. G. Lengnich, op.cit., s. 352-353.

${ }^{69}$ Fraza „złożenia laski”, w znaczeniu formalnego zakończenia obrad sejmu była obecna w źródłach nieformalnych. Lengnich pisze zatem ,gdy już posłowie w izbie obrady swe ukończą, żegna ich marszałek w której wychwaliwszy ich dla Rzeczypospolitej gorliwość (...) poleca się ich względom i urząd swój wraz z laską składa". W ten sposób marszałek ceremonialnie zamyka obrady, ale nie rezygnuje ze swojej godności i kompetencji. Już w kolejnym zdaniu Lengnich stwierdza: „skoro posłowie do izby senatorskiej wnijdą Marszałek tenże (...) oznajmia o ukończeniu wszystkich spraw w izbie (...). Następnie donośnym głosem odczytuje z karty uchwały Posłów”, G. Lengnich, op.cit., s. 368. Marszałek składający laskę zamyka obrady izby, ale nie przestaje być marszałkiem, wykonując istotne kompetencje w trakcie konkluzji, a także po jej zakończeniu. 
statusu wynikające ${ }^{70}$. Twierdzenie Autorki, że po 27 września w diariuszach nazywano Humieckiego marszałkiem niejako automatycznie, „,z przyzwyczajenia piszących" "71 jest całkowicie niepoprawne ${ }^{72}$. Nazywano go marszałkiem konwokacji, bo nim przecież był! I to niezależnie od tego, czy sejm został zerwany czy nie, albo czy marszałek składał tu jakeś szczególne deklaracje, czy nie. Humiecki nie chciał czytać aktu konfederacji i podpisać jego ostatecznej wersji po zgłoszonym przez Horodyńskiego sprzeciwie nie dlatego, że już nie był marszałkiem trwającego sejmu. Czynił to właśnie dlatego, że był marszałkiem sejmu, ale takiego, który został skutecznie zerwany. A sejm taki nie mógł przecież kontynuować swoich obrad. I właśnie jako marszałek sejmu, w związku ze swoimi marszałkowskimi obowiązkami wynikającymi z przysięgi, Humiecki odmówił złożenia podpisu pod aktem konfederacji ${ }^{73}$. Błędna teza prawnicza prowadzi więc autorkę do nieprawidłowej oceny intencji i decyzji politycznych Humieckiego.

${ }^{70}$ Parlamentarzyści byli przecież zobowiązani by złożyć relację przed sejmikiem z wykonania instrukcji, a więc ze sprawowania zakończonej kadencji. Musieli również dostarczyć na sejmik relacyjny tekst wydrukowanych konstytucji sejmu, jeśli zostały uchwalone, por. S. Ochmann-Staniszewska, Z. Staniszewski, op.cit., s. 48-49. Marszałek natomiast zamknąwszy obrady i uzyskawszy status marszałka sejmu zakończonego (,starej laski”) żegnał w imieniu posłów króla i senat i uczestniczył w procesie „ucierania” ostatecznego kształtu uchwał sejmowych na sesjach pieczętarskich. Był także zobowiązany do prowadzenia początkowej fazy obrad kolejnego sejmu aż do skutecznego wyboru nowego dyrektora, odbierał również od niego przysięgę. Trudno nie zgodzić z R. Kołodziejem (op.cit., s. 179), kiedy pisze on, że „wraz z końcem obrad zadania marszałka się nie kończyły”. Marszałek składający laskę nie stawał się nigdy „zwykłym posłem”, nie mógł w czasie konkluzji zrzec się statusu marszałka bez ważnej przyczyny i bez wskazania następcy. Autorka sugeruje jednak - jak się zdaje - że sejm kontynuował swoje obrady bez Humieckiego jako marszałka sejmu, ale z nim w składzie, jako szeregowym posłem.

${ }^{71}$ E. Gąsior, op.cit., s. 231.

72 Dodatkowo wiemy, że Humiecki pełnił również rolę marszałka starej laski na elekcji, co byłoby przecież niemożliwe w przypadku skutecznego „zrzeczenia” się funkcji marszałka konwokacji, por. Humiecki Stefan, h. Junosza (zm. 1736), [w:] L.A. Wierzbicki, Marszałkowie i parlamentarzyści. Studia z dziejów sejmu polskiego w XVII wieku, Warszawa 2014, s. 46.

${ }^{73}$ Tak właśnie interpretowała ten fakt niechętna prymasowi i jego działaniom publicystyka szlachecka, por. Odkryta maszkara przyczyny zerwania seymu Convocationis listem z Warszawy die 19 7bris 1696, B.Ossol., rkps. 652, k. 33. Całość tych rozważań prowadzi w zasadzie donikąd. Wiemy przeciw, że Humiecki swojego podpisu pod aktem konfederacji nie złożył w ogóle. Nie podpisał więc aktu ani jako marszałek, ani jako zwykły, szeregowy poseł, VL, t. V, s. 412-416, fol. 846-856. Zwyczaj umiejscowienia podpisu marszałka jako pierwszego z podpisów poselskich, zamieszczanego zaraz po podpisach senatorskich, był silnie ugruntowany. W podpisach tych marszałkowie zawsze eksponowali swoją marszałkowską godność. W 1632 r. ks. Krzysztof Radziwiłł podpisał się pod aktem jako „Xiążę na Byrżach y Dubiankach, hetman polny W.X.L. marszałek koła poselskiego”, jego podpis znajduje się po ostatnim podpisie senatorskim, złożonym przez Krzysztofa Wiesiołowskiego, marszałka nadwornego litewskiego, a przed podpisami posłów kaliskich i poznańskich, VL, t. III, s. 352, fol. 738. Bogusław Leszczyński podpisał akt konfederacji z 1648 r. jako ,generał wielkopolski, marszałek koła poselskiego", a jego podpis znalazł się pod ostatnim z senatorów marszałku nadwornym litewskim Antonim Janie Tyszkiewiczu, a przed posłami krakowskimi. Pod 
Wyprzedzając nieco rozważania poniższe warto wskazać, że sprawa jest najzupełniej prosta. Część posłów uważała, że sejm zerwany należy po prostu zakończyć bez powzięcia uchwał. Część natomiast wychodziła z założenia, że fakt zerwania sejmu nie może stać na przeszkodzie ustanowieniu pewnej konfederacji „minimum”, koniecznej dla przeprowadzenia elekcji królewskiej i innych czynności w wyjątkowej sytuacji bezkrólewia. Marszałek przychylał się raczej do tej drugiej grupy, ale bał się uwierzytelnienia swoim marszałkowskim (bo innego złożyć nie mógł!) podpisem nielegalnej uchwały (tzn. podjętej bez jednomyślnej zgody i zaakceptowanej po formalnym uznaniu prawidłowego sprzeciwu poselskiego zrywającego sejm). Wynikało to z roty przysięgi marszałkowskiej, którą złożył on w obliczu posłów po wyborze.

Dopiero rozumiejąc powyższe rozważania możemy pojąć dylemat moralny i polityczny stojący za zachowaniem marszałka. Rozumiał on konieczność przyjęcia przez konwokację aktu konfederacji, rozumiał konsekwencje braku aktu dla funkcjonowania państwa. Wiedział, że za brak takiego aktu zostanie napiętnowany on sam - jako marszałek sejmowy. $\mathrm{Z}$ drugiej strony, podpisanie aktu byłoby jawnym krzywoprzysięstwem, którego konsekwencje dla samego Humieckiego były trudne do przewidzenia. Musiał on zatem lawirować, co zresztą skutecznie robił. Znamienne, że rozliczający Humieckiego sejmik relacyjny podolski w ogóle nie porusza tego tematu, uznając po prostu obowiązywanie przyjętego aktu konfederacji i nie komentując postawy swojego przedstawiciela, obdarzonego godnością marszałkowską ${ }^{74}$. Humieckiemu udało się zatem wybrnąć z niewygodnej sytuacji, ale żeby to prawidłowo zrozumieć, trzeba osadzić wydarzenia polityczne w realiach prawnych. Tylko wtedy będą one zrozumiałe. Zawiła argumentacja o jakimś zrzekaniu się laski marszałka, przy dalszym wypełnianiu mandatu poselskiego jest tu zbędna i tylko wprowadza w błąd.

\section{ZERWANIE SEJMU A UCHWALENIE AKTU KONFEDERACJI}

\footnotetext{
aktem konfederacji z 1668 r. Jan Antoni Chrapowicki podpisał się pod ostatnim z senatorów (marszałkiem nadwornym Janem Klemensem Branickim) jako „podkomorzy województwa smoleńskiego marszałek koła poselskiego", VL, t. IV, s. 498, fol. 1060. W akcie z 1674 Jan Franciszek Bieliński podpisał się po podskarbim nadwornym koronnym Stanisławie Lubomirskim, a przed posłami kaliskimi i poznańskimi, jako „miecznik koronny, podkomorzy woiewództwa płockiego, ekonomii malborskiey administrator, osiecki, malborski, mławski starosta, marszałek koła rycerskiego", VL, t. V, s. 129 , fol. 240 .

${ }^{74}$ Szlachta zjechała się na sejmiku ,in fundamento konfederacyjej generalnej, uformowanej po zerwaniu dwuniedzielnej konwokacyjej warszaskiej”, Akta Sejmiku Podolskiego in hostico 1672-1698, wyd. J. Stolnicki, Kraków 2002, s. 200.
} 


\subsection{Teoria rady senatu}

Całość powyższych refleksji prowadzi nas do kluczowego, a nierozstrzygniętego dylematu. Skoro na konwokacji zgłoszono sprzeciw, a jednak doszło do uchwalenia aktu konfederacji, to czy sejm konwokacyjny w 1696 r. został skutecznie zerwany? A jeśli tak, to jaki organ i na jakiej podstawie prawnej uchwalił akt konfederacji?

Wydaje się, że warte rozpatrzenia są dwie teorie. Według pierwszej z nich zerwany skutecznie sejm zakończył się, a po nim zwołana została przez prymasa rada senatu, na którą doproszono posłów i to właśnie ten organ ostatecznie zawiązał konfederację. Druga teza dająca się uzasadnić źródłowo nakazuje przypisać uchwalenie konfederacji samemu sejmowi, mimo formalnego i uznanego sprzeciwu. Ślad obu można znaleźć na kartach monografii. Autorka przyłącza się raczej do drugiego z nich, nie daje nam w tym zakresie żadnych konkretnych dowodów. Warto się zatem przyjrzeć temu problemowi bliżej.

W zakresie pierwszej teorii, Autorka monografii przytacza opinię referendarza Kazimierza Szczuki, że po zerwaniu konwokacji „złożona jest per senatus consilium ekstraordynaryjna konfederacja" ${ }^{75}$. To zupełnie zadziwiające, że to stwierdzenie, bez jakiegokolwiek komentarza, zostało przez Autorkę wciśnięte między zdanie informujące o zgodnym uznaniu obrad sejmu za „pasywne” na skutek protestu a zdanie informujące, że przystąpiono do odczytywania treści aktu konfederacji. A referendarz zasugerował tu przecież, że na skutek zerwania sejmu decyzję odnośnie konfederacji podjął sam senat!

Warto wskazać, że w trakcie obrad, czego Autorka najwyraźniej nie zauważyła, podnoszono ewentualność przejęcia przez senat roli decydenta w sytuacji zerwania sejmu. Jeden z diariuszy przytacza opinię Stanisława Lubomirskiego, marszałka wielkiego koronnego, wygłoszoną w związku ze wspomnianym już sprzeciwem posła Kordysza:

Tandem po explicacyey Imci Pana Marszałka Wielkiego Koronnego, iż za odeyściem wczoray z protestacyą PPosła (...) ustała activitas Imć PPosłów chyba tylko pasive odezwać się mogą. Contra zaś przy PP Senatorach (...) zostaie zawsze ius consullendi, tudzież przy Xiążeciu Imci Prymasie (...). Item że Ichmciom PP. Posłom wolno bywać na radach ${ }^{76}$.

Pomijam kontekst polityczny tych słów i wysnuwane przez autora diariusza przypuszczenie ze swoistą teorią spiskową, według której zerwanie konwokacji zostało zaplanowane właśnie po to, by odebrać szlachcie prawo swobodnego podejmowania decyzji na sejmie. Ważne są dwie zasadnicze, sprzężone ze

\footnotetext{
${ }^{75}$ E. Gąsior, op.cit., s. 231.

${ }^{76}$ AGAD, AR, II-33, s. 334.
} 
sobą interpretacje, które może nie były dominujące, ale istniały w świadomości społecznej. Po pierwsze, wskazano tu, że rady senatu działały w permanencji również w okresie międzysejmowym. Prymas mógł więc zwołać radę w każdej chwili, również zaraz po skutecznym zerwaniu konwokacji. Po drugie, uznawano powszechnie, że skład rad nie był w pełni ustalony, stąd senat mógł na radę doprosić byłych posłów i włączyć ich do obrad. Znajdujący się - jak to już pisałem - w kłopotliwej sytuacji marszałek Humiecki, szukając korzystnego dla siebie rozwiązania dylematu, uciekał się i do tej interpretacji. W swojej mowie końcowej wskazywał: „Żegna Izba Poselska ledwo pożegnany senat oraz żegna fortunam publicam (...). I nie komu inszemu vulnera Reipublicae sananda poleca tylko samemu iaśnie oświeconemu Iasnie Wielmożnemu Senatowi"'77.

Za wskazaną teorią mogą przemawiać jeszcze dwa argumenty natury nie tyle źródłowej, co logicznej. Po pierwsze, zgodnie ze statutami elekcyjnymi Zygmunta Starego, to senat miał prawo wyznaczać czas i miejsce elekcji ${ }^{78}$. W pierwszych bezkrólewiach po 1572 r. stanowiło to przyczynę kontestowania legalności istnienia sejmu konwokacyjnego jako takiego ${ }^{79}$. Po drugie, sam sposób ustanowienia aktu konfederacji z 1696 r. jest wyraźnie wzorowany na procedowaniu rad senatu. Nie mamy swobodnej sejmowej dyskusji, to prymas - przewodniczący obrad, skonkludował je i nakazał odczytanie sformowanego już aktu, do którego nie można się było „przymawiać”. Wszyscy uczestnicy obrad mogli jedynie podpisać tę konkluzję.

Relacje z obrad wskazują na liczne wątpliwości dotyczące realnego wpływu, zwłaszcza posłów, na kształt aktu konfederacji. Został on po prostu odczytany, bez jakiejkolwiek dyskusji; to prymas zupełnie samodzielnie „niektóre punkta wymazał"80. Zgodnie z relacją, będący w większości zwolennicy przyjęcia aktu „niechcieli nikomu dać głosu”. Posłowie małopolscy uzyskali jedynie prawo bliższego zapoznania się z treścią aktu, poza izbą senatorską, gdzie toczyły się obrady. Szlachta „zamknąwszy się czytała ją sobie”, a po powrocie „deklarowała

${ }_{77}$ Mowa Humieckiego Imci przy pożegnaniu izby senatorskiey po rozerwanym seymie convocationis miana..., B.Ossol., rkps. 652, k. 7v.

${ }^{78}$ Por. Ustawy Zygmunta I z lat 1530 i 1538 w sprawie elekcji królewskiej [w:] G. Bałtruszajtis (red.), „Prawo wczoraj i dziś”. Studia dedykowane prof. Katarzynie Sójce-Zielińskiej, Warszawa 2000, s. 349-360.

79 Por. E. Dubas-Urwanowicz, Koronne zjazdy szlacheckie $w$ dwóch pierwszych bezkrólewiach po śmierci Zygmunta Augusta, Białystok 1998, s. 211 i n.; eadem, Dlaczego doszło do zwołania pierwszego sejmu konwokacyjnego? [w:] Chrystianitas et cultura Europae. Ksiega jubileuszowa Prof. J. Kłoczowskiego, Lublin 1998, s. 611-617; S. Adamkiewicz, Skąd się wzięła konwokacja? geneza zjazdu konwokacyjnego $1573 w$ świetle relacji i uniwersatów z koronnych zjazdów szlacheckich w czasie pierwszego interregnum po śmierci Zygmunta Augusta [lipiec-grudzień 1572], [w:] A. Świątek (red.), Per aspera ad astra. Materiały z XVI ogólnopolskiego Zjazdu Historyków Studentów w Krakowie 16-20 kwietnia 2008, t. 5: Historia Rzeczypospolitej Obojga Narodów, Kraków 2008, s. 9-30.

${ }^{80}$ LNB, z. 4, rkps. 66, k. $169 \mathrm{v}$. 
podpisać" ${ }^{\prime 1}$. Przeciwna prymasowi publicystyka zarzucała mu pisanie aktu w prywatnej kwaterze i brak dopełnienia procedur koniecznych dla przyjęcia uchwały ${ }^{82}$. Forma przyjęcia aktu jest zatem zupełnie różna od standardowego akceptowania uchwał sejmowych, przypomina za to mechanikę przyjmowania „rad senatu” jednostronną konkluzją przewodniczącego. Ślady tej procedury znajdujemy w zastrzeżeniach posłów podpisujących akt ${ }^{83}$.

Teoria przyjęcia aktu konfederacji przez posejmową radę senatu z udziałem szlachty byłaby idealnym wyjaśnieniem problematycznego dylematu, godząc fakt niewątpliwego zerwania sejmu $\mathrm{z}$ legalnym przyjęciem aktu konfederacji. W tym układzie uchwała zostałaby przyjęta po prostu przez inny organ aniżeli w pełni legalnie zerwany sejm. Zasadniczą wadą tej teorii jest jednak to, że nie potwierdza jej argumentacja polityków uczestniczących konkluzji sejmu, którą możemy znaleźć w diariuszach. Ani 27 września, ani w dniach następnych nikt już do tej koncepcji nie powrócił, jedynie lawirujący argumentacyjnie marszałek dotknął jej bardzo ogólnikowo w swojej ceremonialnej mowie. Bliższa analiza przebiegu ostatnich sesji sejmu wskazuje jednak, że nie zwołano formalnie żadnej rady senatu i nie przekazano jej kompetencji stanowienia prawa. Byłoby to zresztą ryzykowne, szlachecka opinia publiczna była bardzo wyczulona na punkcie ingerencji rad senatu w materie sejmowe. Warto podkreślić, że intytulacja aktu brzmi standardowo „My Rada i Stany”" Sprzyjająca prymasowi publicystyka stara się tłumaczyć jego zachowanie raczej koniecznością wzięcia odpowiedzialności za kierowanie pracami sejmu w sytuacji uchylania się marszałka od obowiązków po zerwaniu sejmu. Nie przywoływano tu natomiast argumentu z kompetencji rady senatu ${ }^{85}$.

${ }^{81}$ Ibidem, k. 170v.

82 „X. Prymas (...) zaraz intimavit Confoederacyą a oppressi Izby Poselskiey activitate, czytać ią swemu prałatowi kazał, co tylko gotowego było, więcey zaś w domu spisując, nie dawszy do przeczytania publicznego marszałkowi poselskiemu o zgodę ordinum nie spytawszy się, sam onę naprzód podpisał y innych wezwał do podpisu”, Odkryta maszkara..., B.Ossol., rkps. 652, k. 32v.

${ }^{83}$ Podkreślają one poszanowanie dla - jak to modelowo ujął wojewoda krakowski Szczęsny Potocki - ,prerogatyw stanu szlacheckiego, równości iego in Consilijs Status”, VL, t. V, s. 412, fol. 847. Podobne frazy pojawiają się w jeszcze kilku zastrzeżeniach, jest to jednak formuła dość trudna do interpretacji. W czasie sejmu doszło bowiem do spięcia na linii prymas Radziejowski - marszałek Humiecki, które spowodowało zbojkotowanie sesji wspólnej stanów przez większość posłów, która twierdziła, że marszałek został obrażony. Konsekwencją było uznanie, że obrażono cały stan rycerski. Echo widać w asekuracji podskarbiego Hieronima Lubomirskiego, który dopisał pod swoim nazwiskiem ,cum protestatione przeciwko złomanym prerogatywom ordinis equestris $\mathrm{w}$ osobie Marszałka Rycerskiego", VL, t. V, s. 413, fol. 849.

${ }^{84}$ Por. rozważania G. Lengnicha, op.cit., s. 39.

${ }^{85}$ Zdaniem anonimowego autora prymas nie miał wyjścia, gdyż marszałek, mimo istnienia niezbędności aktu dla ocalenia ojczyzny nie chciał „Confoederacyey lubo od siebie pisaney czytać”, 
W konsekwencji należy jednak uznać, że uchwałę, mimo wątpliwości, podjęła - zerwana uprzednio - konwokacja. Takie jest chyba stanowisko Ewy Gąsior, skoro pisze ona, że zerwanie sejmu „nie przeszkodziło" w uchwaleniu aktu i wyznaczeniu daty sejmu elekcyjnego ${ }^{86}$. Niestety Autorka nie zajmuje się tym problemem szerzej.

\subsection{Idea obrony naturalnej i teoria sejmu „naderwanego"}

Warto dodać, że opinię tę zdaje się podzielać Franciszek Salezy Jezierski, który komentował: „Zerwanie seymu było dziwackie, bo chociaż uznali obradę konwokacyi za zerwaną przecież na niey postanowiono czas Elekcyi, bezpieczeństwo wewnętrzne i podaną Konstytucyą, aby nikt z rodaków krajowych nie starał się o koronę”. W dalszej części rozważań nazywa zresztą sejm „naderwanym”87. W konsekwencji Jezierski uznaje, że sejm podjął ważną prawnie uchwałę, mimo że został formalnie zerwany.

Potwierdza tę tezę fakt, że istniała pełna ciągłość obrad zerwanego sejmu i obrad dążących do przyjęcia aktu konfederacji. Ceremonie zamknięcia zerwanego sejmu mieszały się tu z propozycjami, by mimo wszystko przyjąć akt końcowy. Posłowie wyrażali obawy przed przyjęciem aktu, powołując się na ważny sprzeciw i brak activitas sejmu.

Ewa Gąsior nie zastanawia się w ogóle w swojej monografii, jakie było uzasadnienie doktrynalne przyjęcia aktu mimo zerwania sejmu. Pogłębia to wrażenie logicznej sprzeczności jej wywodów. Znamienne, że przytaczając fragment arengi tłumaczący przyjęcie konfederacji Autorka pominęła najważniejszy fragment tego uzasadnienia ${ }^{88}$. Zdaniem sygnatariuszy aktu konfederacji zerwanie konwokacji miało skutkować przeniesieniem wszystkich spraw na sejm elekcyjny z wyjątkiem zamkniętego katalogu problemów koniecznych do rozwiązania przed rozpoczęciem elekcji ${ }^{89}$. W treści aktu scharakteryzowano je jako „naturalem de-

\footnotetext{
Prawda bez maszkary w responsie na list pod tytutem odkryta maszkara, AGAD, AR, II-33, s. 442. Prymas musiał zatem działać na granicy prawa, pod wpływem konieczności i z poczucia obowiązku.

${ }^{86}$ E. Gąsior, op.cit., s. 10, 232.

${ }^{87}$ F.S. Jezierski, op.cit., s. 37-38.

${ }^{88}$ E. Gąsior, op.cit., s. 232.

89 Sygnatariusze zapewniali zatem, że „ex occassione zaszłej kontradykcyi lubo z wielkim żalem y nieukontentowaniem ubliżamy publicis et privatis satisfactionibus, sistimus iednak gradum ad cursum zaczętey konwokacyi, y observando religiossime vocis vetandi unicum et specialissimum jus cardinale, na którym zupełnie prawa swobody y wolności nasze consistent, wszystkie desideria publiczne y prywatne, do przyszłey Elekcyi odkładamy", VL, t. V, 407, fol. 836. Przyjęty akt konfederacji nie jest zatem standardową uchwałą konwokacyjną, ale jej wersją okrojoną. Respektowanie liberum veto nie ma tu wyłącznie charakteru deklaracji, sygnatariusze aktu zapewniają, że realnie ograniczyli zakres regulacji do absolutnego minimum.
} 
fensionem, która każdemu in omni statu existendi iest pozwolona". Co ważne, wymogi owej naturalnej obrony ojczyzny powinny być uważane za pierwotne względem wszelkich praw pozytywnych. Sygnatariusze aktu konfederacji thumaczyli: „naturalem defensionem (...) ante iura et leges Regnorum równo ze światem stanęła" ${ }^{90}$. To błyskotliwe i logiczne uzasadnienie teoretyczne podejmowanej uchwały jest absolutnie kluczowe. Brak jego dogłębnego wyjaśnienia uniemożliwia zrozumienie losów konwokacji z 1696 r. Treść aktu konfederacji wskazuje, że sejm został zerwany zgodnie z prawami Rzeczypospolitej i w normalnych okolicznościach stałoby to na przeszkodzie uchwaleniu przezeń jakichkolwiek norm prawnych. Jednakże owe „stare jak sam świat” oraz „pierwotniejsze od wszelkich praw i ustaw królestwa” wymogi „naturalnej ochrony” ojczyzny w bezkrólewiu wymagały podjęcia uchwały mimo wszystko. W tym kontekście należy odczytywać przyjęte z pewnym zdziwieniem przez Autorkę i przywoływanego przez nią Zbigniewa Radwańskiego szczególne uzasadnienie poszanowania liberum veto $\mathrm{w}$ akcie konfederacji, z podkreśleniem jego statusu jako prawa kardynalnego ${ }^{91}$. Wyjaśnieniem tego passusu nie jest jakieś nagłe podniesienie rangi prawa wolnego głosu posła na sejmie. Takie ujęcie wynikało po prostu z konieczności usprawiedliwienia się przez sygnatariuszy aktu przed opinią publiczną. Zdają się oni stwierdzać - przyjęliśmy uchwałę mimo zerwania sejmu, bo takie były wymogi wypływających z natury praw ratowania ojczyzny, ale szanujemy reguły wolnego głosu i wolnego sprzeciwu na sejmach walnych jako jedno z najistotniejszych praw szlacheckich.

Tę retorykę narzucił sam inicjator przyjęcia uchwały w tym trybie - prymas Radziejowski. Nie negował on wcale skutecznego zerwania konwokacji. Tłumaczył jedynie, że reguły owej naturalnej obrony Ojczyzny usprawiedliwiają fakt zaakceptowania uchwały mimo to: „Xiążę Prymas (...) życzy ad propriam defensionem suii od natury samey nadaney accedere mówiąc do konfederacyey lubo activitas ustała, przetoż ut possumus non ut volumus consulamus Patriae" ${ }^{\text {". Frazy }}$ tej używał Prymas z zadziwiającą regularności i konsekwencją również w posej-

90 Ibidem.

91 E. Gąsior, op.cit., s. 232. Warto zwrócić uwagę na fragment zacytowany przeze mnie w przyp. nr 75. Nie określono tam ius vetandi wyłącznie mianem prawa kardynalnego, sygnatariusze aktu zapewniają przede wszystkim o ortodoksyjnym przestrzeganiu tego prawa. Wszystkie pozostałe określenia mają charakter asekuracji przed opinią publiczną, stąd szeroka, opisowa formuła. Warto wskazać, że pojęcie praw kardynalnych jest używane w języku polityki i prawa staropolskiego od ok. połowy XVII w.

92 B. Ossol., rkps. 652, k. 26. Inne relacje potwierdzają, że motywem decyzji było ,,aby jure naturae o defensyi myśleć", Diariusz Prawdziwy..., s. 426. Argumentacja prymasa zakładał by „udać się do obrony Naturalney ad Confoederationem, gdyż inszego nie masz sposobu (...) tuendi salutem publicam", AGAD, AR, II-33, s. 364-365. 
mowej korespondencji ${ }^{33}$. Odwoływali się do niej również senatorowie ${ }^{94}$. Nie było to wyrażenie przypadkowe, ale fraza mająca opisać spójną logicznie i prawnie koncepcję doktrynalną.

Akceptują tę argumentację nawet przeciwnicy konfederacji, z Janem Odrowążem Pieniążkiem na czele. To interesujące, że jego mowa, mimo iż miała charakter silnie opozycyjny, w zasadzie wyraża zrozumienie dla teoretycznych założeń argumentacji prymasa. Jak już wspominałem, mowa ta powinna być poddana w monografii Ewa Gąsior znacznie głębszej analizie. Pieniążek deklarował: „chcę ia konfederacyey, ale takiey, która prawem Rzpltey opisana iest”. Dodaje następnie: ,nie jestem od tego, abym widząc iuż w ostatniey zgubie Rempublicam zostaiącą, fundując się in iure naturalis defensionis [podkr. - T.K.] (która lex est supra omnes leges [podkr. - T.K.]) nie miał pozwolić na konfederacyą". Jego opór przeciwko prymasowi nie wynikał zatem z odrzucenia jego koncepcji o dopuszczalności przyjęcia konfederacji generalnej mimo zerwania sejmu z powołaniem się na reguły „naturalnej obrony” ojczyzny. Pieniążek uważał tylko, że tekst zaproponowany przez prymasa znacząco wykracza poza ten zakres. Sugerował, że część decyzji mogły z powodzeniem podjąć sejmiki, co pozwoliłoby uniknąć lekceważenia prawa wolnego głosu na sejmie. Wyrażał przy tym gotowość udzielenia zgody na akt konfederacji „tylko w tych punktach jako bez dismembrayi futurum Regnantem ex requisitis obierać będziemy, aby czas wolney elekcyi był naznaczony, aby na seymikach złożonych uchwała płacy na woysko, na rozwiązanie związku [wojskowego Baranowskiego - T.K.] była, aby Piast excludat”. Wyraźnie jednak w akcie zawarto inne kwestie, „które należą do stanu rycerskiego", co zdaniem autora stanowi uzurpację kompetencji ze strony prymasa i senatu ${ }^{95}$.

Podobny ton wyziera $\mathrm{z}$ licznych salw i asekuracji dodawanych do podpisów pod aktem konfederacji. Warto rzucić na nie okiem, żeby przekonać się, że akceptacja dla koncepcji obrony naturalnej była powszechna, choć wątpliwości budził jej zakres. Modelowo wyrażało to zastrzeżenie Ludwika Konstantego Oborskiego, kasztelana liwskiego, który akceptował akt „,cum salvis juribus praesentibus, naprzód na wolną nemine contradicente Elekcyą, na exorbitancyi uspokojenie y mianowanie po trzykroć Króla Imci juxta obloquentiam dawnieyszych Konfederacji, na rozwiązanie związku [wojskowego Baranowskiego - T.K.] et contra machinatores naprzeciw wolney Elekcyi, na czas Elekcyi pro 15 Maij, na deputacją do boku X. Imci Prymasa pro Consilio, a przeciw inszym punktom za zerwaną

${ }^{3}$ Por. np. List Xcia Kardynała Prymasa na seymiki $W^{5} X^{a}$ Litt ${ }^{\circ}$ relacyjne po konwokacyi zerwaney z 15 października 1696 r., LNB, z. 4, rkps. 66, k. 219.

${ }^{94} \mathrm{~Np}$. Wojciech Bereza, wojewoda poznański: ,udawajmy się ad legem naturae ad legem defensionis, do Confoederacyey przystąpmy”, ibidem, k. 170.

${ }_{95}$ B.Ossol., rkps. 652, k. 34. 
Konwokacją ponieważ idzie de praerogativa juris vetandi protestor". Kasztelan klarownie wymienił katalog najważniejszych i nieodzownych jego zdaniem regulacji aktu, rzeczywiście wynikających z doktryny naturalnej obrony ${ }^{96}$. Pozostałe regulacje aktu zostały przez kasztelana odrzucone, z uwagi na fakt, że jako niekonieczne i nienależące do owej „naturalnej ochrony”, zostały objęte skutecznym sprzeciwem i zerwaniem sejmu przez Horodyńskiego. Zbliżone katalogi zawiera kilka innych, podobnie sformułowanych salw ${ }^{97}$.

Argument pozwalający na przyjęcie aktu konfederacji mimo zerwania sejmu, na podstawie odwołania się do teorii obrony naturalnej wydaje się dość oczywisty. Trudno sobie wyobrazić możliwość przeprowadzenia sejmu elekcyjnego w końcu XVII w. bez regulacji konwokacyjnego aktu konfederacji generalnej wyznaczającego przede wszystkim jego czas i miejsce oraz sposób zabezpieczenia procedur elekcyjnych ${ }^{98}$. Akt z 1696 r. budził wątpliwości szlacheckiej opinii publicznej, jednak głównie co do zakresu dopuszczalnej regulacji. Poseł Jan

${ }^{96}$ Należały do nich: gwarancje przebiegu elekcji (ustalenie daty sejmu elekcyjnego, naprawienie egzorbitancji jednomyślny wybór i prawidłowe ogłoszenie króla, przepisy porządkowe dot. bezpiecznego i zgodnego ze standardami demokratycznymi przeprowadzenia elekcji, zwłaszcza względem osób prowadzących nielegalną agitację wyborczą), a także załatwienie najbardziej palących problemów (związku wojskowego i wyboru członków deputacji kontrolnej „do boku” prymasa), VL, t. V, s. 413, fol. 849.

${ }^{97}$ Wymienię kilka najbardziej klarownych treściowo salw o podobnej treści. Na obronę naturalną wyraźnie powoływał się Jan Stanisław Zbąski, biskup warmiński: ,praesentem actum, necessitate Reip. defensionis adactus". Marszałek wielki koronny Stanisław Lubomirski wymieniał w tym kontekście akceptowane przez siebie przepisy, stanowiące wynik akceptacji doktryny naturalnej obrony: gwarancje wolności elekcji, czas elekcji, bezpieczeństwo wewnętrzne i zewnętrzne. Zaznaczał przy tym wyłączenie „caeteris punctis que non videbantur Reip. acceptabilia”. Podkreślał bowiem, że niektóre punkty aktu „ad libertatem et ordinem Confoederationis non pertinent ob rationem protestationis Nuntij absentis et immunitatem juris vetandi”. Podkanclerzy litewski Karol Stanisław Radziwiłł wyłączał ze swojej akceptacji wszystkie punkty „que prorsus non sapiunt securitatem internam et externam". Podskarbi koronny Hieronim Lubomirski wymieniał jako konieczne i akceptowane przez siebie: termin elekcji, „sposób rozwiązania związku”, deputację do boku prymasa, wyłączenie biernego prawa wyborczego dla kandydatów krajowych oraz bezpieczeństwo wewnętrzne i zewnętrzne państwa, dodając, że jest „przeciwko materiom do Konfederacyi contra ius vetandi należącym". Podobnie poseł Jan Stanisław Giżycki z ziemi czerskiej deklarował „piszemy się in his punctis na”, po czym wymienił akceptowane przez siebie regulacje: gwarancje wolności elekcji, jej jednomyślność oraz prawidłowe potwierdzenie, termin sejmu elekcyjnego i naprawa egzorbitancji, a także deputację do boku prymasa, rozwiązanie związku wojskowego i regulacje dotyczące osób nielegalnie prowadzących agitację elekcyjną. Co do reszty aktu zaznaczał, że jest ,przeciw innym punktom, ponieważ idzie de praerogativa jus vetandi”. Posłowie podlascy, Aleksander Butler z ziemi drohickiej oraz posłowie z ziemi mielnickiej wyrazili wyraźną zgodę na gwarancję wolności elekcji, termin elekcji, rozwiązanie związku wojskowego i spłacenie zaległego żołdu, deputację do boku prymasa. Co do pozostałej części aktu posłowie deklarowali „contra caetera puncta protestamur", VL, t. V, s. 412-416, fol. 846-856.

${ }_{98}$ O roli przepisów o porządku elekcji, które regularnie umieszczano w aktach konfederacji generalnych warszawskich, uchwalanych na sejmach konwokacyjnych pisałem w innym miejscu, por. 
Jakub Potulicki, starosta borzechowski, mówił wprost: „nie wstyd mię iednak spytać iak konfederacyą pisać będziemy, kiedy non restituta activitatem" ${ }^{\prime 99}$. Wniósł on nawet - bardzo pomysłowo zresztą - by zmienić nazwę aktu i przez to nadać mu nieco mniej kontrowersyjny charakter. Zaproponował formę prawną manifestacji (,życzyłbym status manifestatio napisać") ${ }^{100}$. Propozycja ta nie została jednak przyjęta przychylnie, „krzyknęli wszyscy na niego, że novitatem wniósł”101. Po pierwsze, manifestacje nie mogły przecież zawierać skutecznych i egzekwowalnych norm prawnych. Po drugie, zgodnie z prawem zwyczajowym kluczowe dla bezkrólewia kwestie regulowano wyłącznie na konwokacji i wyłącznie aktem konfederacji generalnej. W konsekwencji akt konfederacji (o mocy równej konstytucjom sejmowym) był jedynym możliwym rozwiązaniem. Potwierdzał to prymas Radziejowski, który błyskotliwie próbował zdjąć z siebie odpowiedzialność za przyjęcie aktu w takiej formie mimo zerwania sejmu i tłumaczył posłom: ,jeśli się komu konfederacya niepodoba niech da sposób inszy, niech inszą poda radę a ia ią przyimę". Wskazywał jednocześnie, że jakieś decyzje w związku z bezkrólewiem przyjąć trzeba, bo - jak zauważył patetycznie - „niegodzi się porzucać ojczyzny"102. Oczywiście w pismach ulotnych zdarzały się nieliczne głosy kwestionujące czy poddające w wątpliwość samą teorię obrony naturalnej, nie miały one jednak znaczenia dla praktyki politycznej ${ }^{103}$.

Spór ten jest jednak świadectwem silnych skrupułów posłów przed podpisaniem aktu. Wyrazem owych skrupułów są liczne salwy dopisywane do podpisów pod aktem konfederacji, wyraźnie potwierdzające ważność wolnego głosu i wolnego sprzeciwu na sejmie. Przede wszystkim widać tu jednak silne przywiązanie do ukształtowanych reguł przeprowadzania sejmu konwokacyjnego, wbrew twierdzeniom o ich niesprecyzowanym charakterze głoszonym przez Olszewskiego i Gąsior. Nikt w trakcie sejmowej dyskusji nie zakwestionował jednomyślnego

T. Kucharski, Przepisy porządkowe na zjazdach elekcyjnych w latach 1587-1674, „Studia Iuridica Toruniensia" 2012, X, s. 82-122.

${ }_{99}$ LNB, z. 4, rkps. 66, k. 168.

${ }^{100}$ Według innej wersji: ,rozumiałby tedy żeby raczey nie confoederacyą nazywać, ale Manifestacyą w którey by się mogło wyrazić wszystko", AGAD, AR, II-33, s. 365.

${ }^{101}$ LNB, z. 4, rkps. 66, k. 168v.

102 Ibidem, k. 170.

${ }^{103} \mathrm{~W}$ jednym z dialogów publicystycznych między Senatorem i Szlachcicem, ten drugi mówił: „Nie jestem satisfactus (...), że po zerwaney Conwokacyey formata et firmata confoederacya”. Wyrażał przy tym przekonanie, że teoria obrony naturalnej to tylko pretekst, bezwartościowa próba usprawiedliwienia jawnego złamania prawa. Przyjęcie aktu mimo zerwania sejmu miało oznaczać „ogłodzenie vocis vetandi”, okraszone nic nieznaczącym tłumaczeniem, że obecni zdecydowali się zaakceptować akt „niechcąc niby liberae voci derogare nihil sub praetexstu naturalney obrony”. Zdaniem autora ,przez wyrażenia zaś, że stante contradictione stanęła confoederacya, vocis vetandi libertas prawie zniesiona", Sermo familiaris Senatora z Szlachcicem, AGAD, AR, II-33, s. 446. 
trybu głosowania na konwokacji. Nikt nie przywołał domniemanej zasady zakazu jej zerwania. Dotyczyło to nawet zwolenników przyjęcia aktu konfederacji mimo sprzeciwu Horodyńskiego.

\subsection{Problem ratyfikacji przez sejmiki}

Zupełnie wyjątkowa jest treść znacznej części zastrzeżeń, które wprost kwestionowały prawomocność uchwały konwokacyjnej domagając się jej „ratyfikacji”, czyli zatwierdzenia przez sejmiki. Cum salva ratihabitione akt konfederacji podpisało aż 12 senatorów i 21 posłów ${ }^{104}$.

Monografia Ewy Gąsior nie docenia niestety owej roli ratyfikacyjnej sejmików. Analizując konkretne lauda pokonwokacyjne, Autorka wspomina jedynie o zawiązaniu konfederacji województw kujawskich po zerwanym sejmiku ${ }^{105}$. Znacznie lepiej problem ratyfikowania aktu konfederacji widać w uchwale poznańsko-kaliskiej. Szlachta wielkopolska deklarowała: „Tedy my in tuitionem wolności naszej generalną konfederacyją warszawską, po zerwanej konwokacji spisaną, manutenemus i tak onę, jako i particularem confoederationem województw naszych in toto reasumimus i hoc laudo nostro, po trzecie sprzysięgamy się i hac honore et conscientiis nostris obowiązujemy się, przy wolności i swobodach naszych, a najwięcej circa liberam electionem futuri reganti (...) jednostajnie i nierozdzielnie stawać". Jednocześnie osobno potwierdzono uchwalony w akcie konfederacji czas elekcji, szlachta zadeklarowała, że przeznaczony na początek sejmu elekcyjnego dzień 15 maja 1697 r. „W konfederacyjej warszawskiej wyrażony akceptujemy"106.

104 VL, t. V, s. 412-417, fol. 846-860. Wśród senatorów byli to wojewodowie: poznański (Wojciech Bereza), sandomierski (Michał Warszycki), kaliski (Stanisław Małachowski), ruski (Marek Matczyński), bełski (A. Sieniawski), pomorski (Jan Gniński); kasztelanowie: wojnicki (Przecław Szembek), sieradzki (Aleksander Lipski), brzeskokujawski (Kazimierz Grudziński), inowrocławski (Franciszek Grzybowski), kruszwicki (Jan Chryzostom Czapski) oraz jeden minister - podkanclerzy litewski Karol Stanisław Radziwiłł. Posłowie żądający ratyfikacji reprezentowali 10 sejmików: poznański, wiłkomirski, sandomierski, kaliski, sieradzki, brzeskokujawski, zakroczymski, łomżański, podlaski (ziemi bielskiej) i gostyński.

${ }^{105}$ Autorka nie przyjrzała się przy tym bliżej treści tej uchwały. Widoczny jest w niej przede wszystkim niepokój szlachty kujawskiej z powodu losów jej własnego sejmiku przedkonwoakcyjnego ,ponieważ mało tych województw eventu et infelici fato sejmik antekonwokacyalny (...) nam zerwany na którym more majorum nostrorum do konfederacyi województw naszych spisania nie przyszło, ani do obrania sędziów kapturowych, ani sądów postanowienia”. W konsekwencji również „W generalną konfederacyą warszawską województwa nasze nie weszły”, a więc sygnatariusze aktu zadeklarowali „konfederacyą generalną warszawską, uti necessarium rzeczy libertates caedentem, in toto przyjmujemy i do niej się konformujemy", Dzieje Ziemi Kujawskiej, wyd. A. Pawiński, Warszawa 1888, t. III, s. 196-197.

${ }^{106}$ Akta sejmikowe województw poznańskiego i kaliskiego. Lata 1696-1732, wyd. M. Zwierzykowski, Poznań 2008, s. 54. 
Jak widać, dyrektywa ratyfikowania aktu konfederacji, jej reasumowania i potwierdzania nie była pustą deklaracją z salw, ale naprawdę została zrealizowana przez cześć sejmików. Wystarczy sobie porównać uchwałę sejmiku relacyjnego kalisko-poznańskiego z 1696 r. ze standardowymi uchwałami tego typu po kolejnych konwokacjach siedemnastowiecznych. W uchwałach tych zgromadzona szlachta powołuje się po prostu na uchwalony akt konfederacji generalnej i zapowiada wykonanie jego najważniejszych elementów, zwłaszcza tych dotyczących obrony ${ }^{107}$. Formuła, do której odwołała się szlachta wielkopolska w 1696 r. jest rzeczywiście unikatowa i świadczy o swoistej próbie ratyfikowania czy też konwalidacji „kulejącego” w sensie prawnym aktu konfederacji.

\section{PODSUMOWANIE}

Celem niniejszego szkicu nie było złośliwe piętnowanie monografii pióra Ewy Gąsior. Praca ta pod względem zebranego materiału źródłowego powinna być oceniona pozytywnie, traci niestety na niezgłębieniu literatury pośrednio związanej z tematem, a także bardzo pobieżnym i lapidarnym intepretowaniu licznych źródeł odnoszących się do skomplikowanych realiów prawnych i politycznych bezkrólewia po śmierci Jana III. Moim zdaniem jest to wyraz szerszej tendencji - kryzysu klasycznego modelu monografii konkretnych sejmów walnych, zapoczątkowanych przez pionierską pracę Władysława Czaplińskiego ${ }^{108}$. Jest to szczególnie widoczne w pracach o sejmach z okresu po potopie szwedzkim, kiedy znacząco wzrasta liczba źródeł (większość monografii z lat 70. i 80. XX w. dotyczyła okresu przed potopem, głównie 1 poł. XVII w.).

Podstawowym założeniem mojej refleksji było jednak pokazanie, że analizy prawnicze w pracach historycznych nie są pustym „dogmatyzowaniem”, które historykowi-specjaliście od dziejów polityki czy gospodarki nie jest do niczego potrzebne. Sfery prawa i polityki przeplatają się ze sobą i prace historyczne potrzebują fachowego wsparcia historii prawa do prawidłowego prowadzenia badań. Taka jest zresztą - nie ma się tu co obrażać - służebna rola historii prawa. Służebna podwójnie, bo podpierająca swoim warsztatem zarówno nauki historyczne, jak i dogmatyczne rozważania prawne nad współczesnymi instytucjami prawnymi.

107 Por. laudum z 13 września 1632 r., B.Racz., rkps. 231-1, s. 295 i n.; laudum przy „okazowaniu” z 4 kwietnia 1669 r., B.Racz., rkps. 231-2, s. 164 i n.; laudum z 15 marca 1674 r., B.Racz., rkps. 231-2, s. 366 i n.

${ }_{108}$ W. Czapliński, Dwa sejmy w roku 1652. Studium z dziejów rozkładu Rzeczypospolitej szlacheckiej w XVII wieku, Wrocław 1955. 